\title{
Investigating the stomatal, cuticular and soil ammonia fluxes over a growing tritical crop under high acidic loads
}

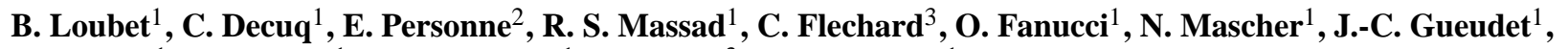 \\ S. Masson ${ }^{1}$, B. Durand ${ }^{1}$, S. Genermont ${ }^{1}$, Y. Fauvel ${ }^{3}$, and P. Cellier ${ }^{1}$ \\ ${ }^{1}$ INRA, UMR 1091-INRA-AgroParisTech, Environnement et Grandes Cultures, 78850 Thiverval-Grignon, France \\ ${ }^{2}$ AgroParisTech, UMR 1091-INRA-AgroParisTech, Environnement et Grandes Cultures, 78850 Thiverval-Grignon, France \\ ${ }^{3}$ INRA, AgroCampus Ouest, UMR 1069 SAS, 65, rue de St-Brieuc, 35042 Rennes, France
}

Correspondence to: B. Loubet (loubet@grignon.inra.fr)

Received: 19 September 2011 - Published in Biogeosciences Discuss.: 24 October 2011

Revised: 14 February 2012 - Accepted: 2 April 2012 - Published: 26 April 2012

\begin{abstract}
Ammonia concentration and fluxes were measured above a growing triticale field for two months during May and June 2010 at the NitroEurope crop site in Grignon (Fr-Gri) near Paris, France. The measurement campaign started 15 days following a $40 \mathrm{~kg} \mathrm{~N} \mathrm{ha}^{-1}$ application of an ammonium nitrate solution. A new mini-wedd (Wet Effluent Denuder) flow injection analyser with three channels (ROSAA, RObust and Sensitive Ammonia Analyser) was used to measure $\mathrm{NH}_{3}$ fluxes using the aerodynamic gradient method. The measured ammonia concentrations varied from 0.01 to $39 \mu \mathrm{NH}_{3} \mathrm{~m}^{-3}$ and were largely influenced by advection from the nearby farm. The ammonia fluxes ranged from -560 to $220 \mathrm{ng} \mathrm{NH}_{3} \mathrm{~m}^{-2} \mathrm{~s}^{-1}$ and averaged $-29 \mathrm{ng} \mathrm{NH}_{3} \mathrm{~m}^{-2} \mathrm{~s}^{-1}$. During some periods the large deposition fluxes could only be explained by a very small surface resistance, which may be partly due to the high concentrations of certain acid gases $\left(\mathrm{HNO}_{3}\right.$ and $\left.\mathrm{SO}_{2}\right)$ observed in this suburban area. Ammonia emissions were also observed. The canopy compensation point $C_{\mathrm{c}}$ was around $1.5 \mu \mathrm{g} \mathrm{NH} \mathrm{N}_{3} \mathrm{~m}^{-3}$ on average. The canopy emission potential $\Gamma_{\mathrm{c}}\left(C_{\mathrm{c}}\right.$ normalised for the temperature response of the Henry equilibrium) decreased over the course of the measurement campaign from $\Gamma_{\mathrm{c}}=2200$ to $\Gamma_{\mathrm{c}}=450$, the latter value being close to the median stomatal emission potential $\left(\Gamma_{\mathrm{S}}\right)$ and lower than the median ground emission potential $\left(\Gamma_{\mathrm{g}}\right)$ for managed ecosystems reported in the literature. The temporal dynamics of the measured $\mathrm{NH}_{3}$ flux compared well with the Surfatm- $\mathrm{NH}_{3}$ model using fitted parameters. The subjectivity of the model fitting is discussed based on a sensitivity analysis.
\end{abstract}

\section{Introduction}

Following a series of UNECE protocols, a significant decrease of sulphur and nitrogen oxides emissions was recorded in Europe in the last 30 years. This led to reduced nitrogen $\left(\mathrm{NH}_{\mathrm{x}}\right)$ becoming the dominant atmospheric pollutant contributing to the acidification of ecosystems in Western Europe. At the global scale emissions of $\mathrm{NH}_{\mathrm{x}}$ and of nitrogen oxides $\left(\mathrm{NO}_{\mathrm{x}}\right)$ are comparable, although large uncertainties exist on $\mathrm{NH}_{\mathrm{x}}$ emissions (Bouwman et al., 1997; Dentener and Crutzen, 1994). Moreover, $\mathrm{NH}_{\mathrm{X}}$ deposition, along with other reactive nitrogen deposition $\left(\mathrm{NO}_{\mathrm{x}}, \mathrm{HNO}_{3}\right)$, leads to eutrophication and induces changes in the biodiversity of terrestrial and aquatic ecosystems (Fangmeier et al., 1994; Krupa, 2003), and may also lead to increased greenhouse gases emissions (such as nitrous oxide $\mathrm{N}_{2} \mathrm{O}$; Melillo et al., 1989) and to reduced methane oxidation by soils $\left(\mathrm{CH}_{4}\right.$; MacDonald et al., 1997). There is also a debate as to the extent to which atmospheric nitrogen inputs to forests increase carbon uptake (De Schrijver et al., 2008; de Vries et al., 2008; Magnani et al., 2007). Additionally, ammonium sulphate aerosols, $\left(\mathrm{NH}_{4}\right)_{2} \mathrm{SO}_{4}$, contribute to half of the negative radiative forcing of the atmosphere due to aerosols (Adams et al., 2001; Houghton et al., 2001), and also impact human health. At the global scale the use of synthetic fertiliser has dramatically increased over the past century since the discovery of the "Haber-Bosch process" (Howard and Rees, 1996), a trend which is expected to increase in the future with increasing demand for food consumption and biofuels (Erisman and Sutton, 2008; Galloway et al., 2008). These trends 
are expected to lead to an increasing pool of reactive nitrogen in the environment, which unfortunately is not recycled efficiently for food production, the so-called "Nitrogen cascade" effect (Galloway et al., 2008). If no drastic changes take place in consumption patterns and environmental policies, it is expected that the impacts of reduced nitrogen on the environment will become a major issue in the coming decades (Sutton et al., 2011).

It has been known since the end of the 19th century (Eriksson, 1952; Sutton et al., 2008) that ammonia mainly originates from livestock (Bouwman et al., 1997; Dammgen et al., 2005; Misselbrook et al., 2000). The main $\mathrm{NH}_{\mathrm{x}}$ sources are housing and waste storage (Bussink and Oenema, 1998), and land spread manure (Génermont and Cellier, 1997; Sommer et al., 2003). Hence the main $\mathrm{NH}_{\mathrm{x}}$ emissions originate from "hot spots" sources in the sense that they are intense and either of limited spatial extent (point sources, such as animal houses and manure storage) or temporally short (manure application) (Loubet et al., 2009; Loubet et al., 2010).

The ammonia emitted to the atmosphere is ultimately dry and wet deposited to the Earth's surface, either locally or at larger distances (Asman, 2001; Loubet et al., 2009). Ammonia can also be emitted from terrestrial ecosystems as a result of the compensation point between consumption and production processes (Farquhar et al., 1980; Sutton et al., 1993). There are several pathways of $\mathrm{NH}_{3}$ exchange between the atmosphere and terrestrial ecosystems: the soil and litter, the external surfaces of the leaves and stems, the stomata and the chemical interactions within the canopy air space. In fertilised crops, ammonia can be volatilised from the canopy, whereas net deposition is more likely on seminatural ecosystems (Fowler et al., 2009; Massad et al., 2010). However, as a result of the complex interactions between the sources and sinks within a canopy (turbulent transfers between the canopy compartments), a fertilised crop may also behave as a sink for $\mathrm{NH}_{3}$, especially downwind from $\mathrm{NH}_{3}$ hot spots where atmospheric $\mathrm{NH}_{3}$ concentration can be high. The GRAMINAE Integrated Experiment has shown that in grasslands the litter and the soil were the main potential sources of $\mathrm{NH}_{3}$, while the growing leaves always had a lower emission potential. However, in the GRAMINAE Integrated Experiment, the litter and soil did not contribute to the total flux above a tall canopy because of (i) a large aerodynamic resistance and (ii) recapture from the upper layer of the canopy (Sutton et al., 2007; Sutton et al., 2009a). The presence of acid compounds onto the leaves enhances $\mathrm{NH}_{3}$ deposition (Erisman et al., 1997; Erisman and Wyers, 1993; Flechard et al., 1999; Flechard et al., 2011; Massad et al., 2010). This enhancement is modelled in EMEP-03 by an exponential decrease of the cuticular resistance with the ratio of atmospheric $\mathrm{SO}_{2}$ to $\mathrm{NH}_{3}$ mixing ratios (Nemitz et al., 2001; Simpson et al.,2003).

The number of studies reporting $\mathrm{NH}_{3}$ flux measurements is rather limited. There are a few studies reporting ammonia flux measurements over grassland (Flechard et al., 2010;
Milford et al., 2009; Sutton et al., 2009a, 2009b; Wichink Kruit et al., 2007), and semi-natural ecosystems (Flechard and Fowler, 1998a; Flechard and Fowler, 1998b; Flechard et al., 1999). However, even if the previous ecosystems have not been extensively studied, there are even less reference fluxes above croplands (Sutton et al., 1995), and most of them focus on $\mathrm{NH}_{3}$ volatilisation following fertiliser application or slurry spreading (Genermont et al., 1998; Loubet et al., 2010). Schjoerring and Mattsson (2001) report emissions from a barley wheat, oilseed rape and pea rotation, with a peak emission at senescence. Nemitz et al. (2000) show also that oilseed rape is a net source of $\mathrm{NH}_{3}$ to the atmosphere with the litter and the silliques being a source and the leaves being a sink. Neftel et al. (1998) report measurements of soil and canopy $\mathrm{NH}_{3}$ concentrations in a triticale field showing that the field was mainly a sink for $\mathrm{NH}_{3}$ in June and July (field fertilised in March).

In this study we analyse the partitioning of the $\mathrm{NH}_{3}$ flux between the soil, the stomatal and the cuticular pathways in a triticale crop. This analysis is based on two months of measurements of $\mathrm{NH}_{3}$ concentrations and fluxes using the aerodynamic gradient method and a mini-wedd (wet effluent denuder) system. The stomatal, cuticular and soil relative contributions to the net fluxes are estimated and the soil potential emission is determined, using the Surfatm- $\mathrm{NH}_{3}$ model (Personne et al., 2009) as a comparison and interpretation tool. Finally, the cuticular resistance is discussed, accounting for the measured gaseous acid concentrations at the site.

\section{Material and methods}

\subsection{Field site}

The experimental campaign was carried out at the Grignon cropland site (NitroEurope IP and FLUXNET field site FRGri, $48^{\circ} 51^{\prime} \mathrm{N}, 1^{\circ} 58^{\prime} \mathrm{E}$ ), located $30 \mathrm{~km}$ south-west of Paris (France) at $125 \mathrm{~m}$ a.m.s.l. The field consisted of a 19 ha triticale crop (Talentro) which was sown on 14 October 2009 and harvested on 19 July 2010. The soil type is classified as luvisol (loamy clay: $25 \%$ Clay, $70 \%$ Silt, $5 \%$ Sand) and the terrain has a slight slope of about $1 \%$. The mean annual temperature is $11.5^{\circ} \mathrm{C}$ with a mean annual precipitation of $700 \mathrm{~mm}$; the main wind directions are north-west/southwest. The field is located to the north east of the AgroParisTech experimental farm (at approximately $460 \mathrm{~m}$ ). The farm has a substantial animal production with 210 dairy cattle, 510 sheep (milk and meat) and a production of 900 lambs per year on average (Fig. 1).

The experiment took place between 27/04/2010 and $30 / 06 / 2010$. The field received 60 and $40 \mathrm{~kg} \mathrm{~N} \mathrm{ha}^{-1}$ as a $39 \%-\mathrm{N}$ ammonium nitrate solution on 17/03/2010 and $10 / 04 / 2010$, respectively. After the second nitrogen application, the cumulated precipitation was only $1.6 \mathrm{~mm}$ before the start of the experiment (rain only occurred on 12/04/2010). 


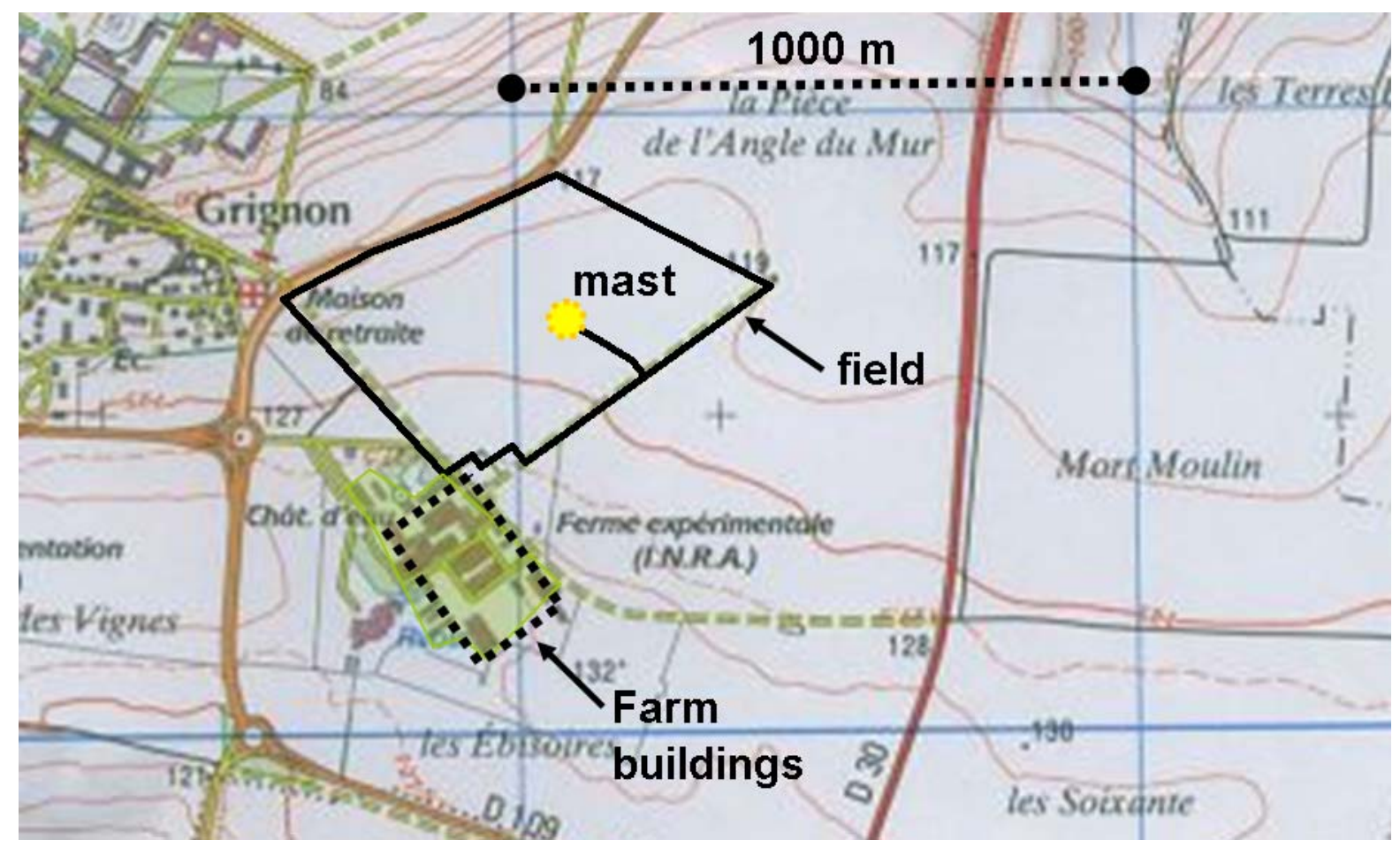

Fig. 1. Map of the experimental area showing the field (solid black line), the farm buildings (dotted line) and the mast location (yellow dot).

During the experimental campaign the crop grew from $0.5 \mathrm{~m}$ to around $0.95 \mathrm{~m}$, and the one sided leaf area index (LAI) changed from 3 to $4 \mathrm{~m}^{2} \mathrm{~m}^{-2}$ during the experiment.

\subsection{Micrometeorological measurements}

The wind velocity $(U)$, the wind direction (WD), the friction velocity $\left(u_{*}\right)$, the latent (LE) and sensible $(H)$ heat fluxes were measured following the NitroEurope-CarboEurope methodology (Aubinet et al., 2000; Loubet et al., 2011). An R3-50 ultrasonic anemometer (Gill Instruments Ltd. UK) was positioned at $3.17 \mathrm{~m}$ above the ground to record the wind velocity components at $50 \mathrm{~Hz}$, while the $\mathrm{CO}_{2}$ and $\mathrm{H}_{2} \mathrm{O}$ concentrations were measured at $20 \mathrm{~Hz}$ with an open path $\mathrm{Li}$ 7500 Infra Red Gas Analyzer (Licor, USA) placed around $20 \mathrm{~cm}$ apart. The data were acquired through an RS485 connection with a Labview program (NI, USA) and stored in a computer prior to post-processing. Each signal was "despiked" and block-averaged every 30 minutes, apart from $T_{\mathrm{a}}$ (air temperature), which was detrended. A planar fit rotation was applied on the whole period to correct for the mast inclination. The latent heat fluxes were corrected for the variation in air density due to simultaneous transfers of sensible heat and water vapour following the WPL method (Webb Pearson Leuning) as in Aubinet et al. (2000). The $\mathrm{CO}_{2} / \mathrm{H}_{2} \mathrm{O}$ open path analyser was also used to determine a wetness index (WI) which was set to 1 when the Li-7500 was saturated with water within the $30 \mathrm{~min}$ period and 0 otherwise (these periods were flagged when the $\mathrm{H}_{2} \mathrm{O}$ concentration returned by the instrument was higher than $10000 \mu \mathrm{mol} \mathrm{m}^{-3}$ over $30 \mathrm{~min}$ ).

Incoming global solar radiation $\left(R_{\mathrm{g}}\right)$ and net radiation $\left(R_{\mathrm{n}}\right)$ were measured at $2 \mathrm{~m}$ height with a pyranometer (Kipp $\&$ Zonen CM7B Albedometer) and a net pyrradiometer (NRLite, Kipp et Zonen). Air relative humidity (RH) and temperature $\left(T_{\mathrm{a}}\right)$ were measured at the same height with an HMP35 (Vaisala, FI) and copper-constantan thermocouple with ventilated radiation shields. The ground heat flux $(G)$ was measured with two flux plates, and the soil temperature was measured at 5 depths with copper-constantan thermocouples. The soil humidity was measured with TDR probes (TIme Domain Reflectometry, Campbell Sci., USA.) at 5 , and $30 \mathrm{~cm}$ depths. A wind speed profile was set up at heights $(0.3,0.7$, $1.0,1.4,2.0,2.7,3.8,5.3$ and $7.5 \mathrm{~m}$ ) with cup anemometers (model CE 155, Cimel Electronique, Paris, France). A data-logger was used to store the meteorological data (CR10, Campbell Scientific, Logan, UT, USA) every $5 \mathrm{~s}$ and then averaged over $30 \mathrm{~min}$.

\subsection{Ammonia concentrations}

Ammonia concentrations were measured with three acid coated wet effluent denuders (mini-wedd) coupled with a flow injection analyser through storage units (ROSAA, Robust and Sensitive Ammonia Analyser, patent registration 10 55253, UCPI, France). The ammonia is trapped in an acidic stripping solution and stored in flasks before being 
analysed sequentially with a conductimeter coupled to a semi-permeable membrane every $30 \mathrm{~min}$. A $1 \mathrm{~L} \mathrm{~min}^{-1}$ air flow rate is imposed with mass flow controllers, while the quantity of liquid flow stored in each flask (between 6 and 10 $\mathrm{ml}$ ) is sequentially determined with a balance every $30 \mathrm{~min}$. The mini-wedds were designed to sample only the gas-phase $\mathrm{NH}_{3}$ and not the aerosol phase $\left(\mathrm{NH}_{4}^{+}\right)$. The yield of a miniwedd was determined during a testing phase in the lab by sampling through two subsequent denuders and found to be larger than $98 \%$. The stripping solution was a weak acid (sodium hydrogen sulphate monohydrate at $0.5 \mathrm{~g} \mathrm{~L}^{-1}$ ). Four liquid ammonium standard solutions were used to calibrate the analyser every $2 \mathrm{~h}$. During the campaign, the calibration standards were changed on 22/04 (103, 238, 511, $749 \mathrm{ppb}$ $\left.\mathrm{NH}_{4}^{+}\right)$, on $18 / 05\left(51,104,259,506 \mathrm{ppb} \mathrm{NH}_{4}^{+}\right)$and on 15/06 $\left(53,103,262,416 \mathrm{ppb} \mathrm{NH}_{4}^{+}\right)$. Moreover, a quality control solution (QC) of $375 \mathrm{ppb} \mathrm{NH}_{4}^{+}$(before 18/05) and $214 \mathrm{ppb}$ $\mathrm{NH}_{4}^{+}$(afterwards) was passed every $6 \mathrm{~h}$ during the experiment to check the quality of the measurements. These QC measurements were then used afterwards to correct the measured concentration for the systematic difference observed: the concentration was multiplied by the ratio of the theoretical to the measured QC over the entire period for each QC. The systematic difference between the denuders was investigated before the experiment in the lab. Step concentrations at $60 \mu \mathrm{g} \mathrm{NH}_{3} \mathrm{~m}^{-3}, 260 \mu \mathrm{g} \mathrm{NH}_{3} \mathrm{~m}^{-3}$ and $1160 \mu \mathrm{g} \mathrm{NH}_{3} \mathrm{~m}^{-3}$ were generated using a permeation device. We did not achieve stable concentrations at lower levels due to $\mathrm{NH}_{3}$ stickiness and therefore only tested these high $\mathrm{NH}_{3}$ levels. We found that the denuders were reading the same concentration with an accuracy of $4.4 \%$. The systematic differences between the denuders were not controlled during the course of the experiment. However, the design of the denuders should have limited these systematic differences. Figure 2 gives a schematic of the ROSAA analyser

Additionally, the concentrations of gaseous ammonia $\left(\mathrm{NH}_{3}\right)$ were measured monthly with the DELTA system located at $1.5 \mathrm{~m}$ height (Sutton et al., 2001; Tang et al., 2009). The DELTA system consisted of a train of doubled coated borosilicate glass denuders for gases and a two stage coated paper filter for aerosols. See Tang et al. (2009) for a description of the system.

\subsection{Ammonia fluxes with the aerodynamic gradient method}

The ecosystem/atmosphere $\mathrm{NH}_{3}$ flux was estimated using the aerodynamic gradient method, following the approach described in Sutton et al. (1993). The mini-wedds were positioned at $0.53,0.83$ and $1.43 \mathrm{~m}$ height on $22 / 04$ and moved twice: to $0.70,0.83$ and $1.43 \mathrm{~m}$ on $07 / 05$ and $0.98,1.25$ and $1.79 \mathrm{~m}$ on $20 / 05$ to accommodate the canopy growth.
The flux was estimated using the concentration scaling pa$\operatorname{rameter}\left(C_{*}\right)$ as:

$F_{\mathrm{NH}_{3}}=-u_{*} C_{*}$

with emission fluxes denoted as being positive. $C_{*}$ was calculated as:

$C_{*}=k \frac{\partial C_{\mathrm{NH}_{3}}}{\partial\left[\ln (z-d)-\Psi_{\mathrm{H}}\left(\frac{z-d}{L}\right)\right]}$

where $k$ is von Karman's constant $(k=0.41), z$ is height above the ground surface, $d$ is zero plane displacement, $C_{\mathrm{NH}_{3}}$ is the $\mathrm{NH}_{3}$ concentration measured with the ROSAA analyser and $\Psi_{H}$ is the integrated stability correction function for heat and trace gases, calculated from the Monin-Obukhov length (L) according to the description of Sutton et al. (1993). The friction velocity $\left(u_{*}\right)$ was obtained from the eddy covariance dataset and the Monin-Obukhov length $(L)$, which was calculated as:

$L=-\frac{u_{*}^{3} \rho C_{p}\left(T_{\mathrm{a}}+273.15\right)}{k g H}$

Where $g$ is the gravitational acceleration $\left(9.81 \mathrm{~m} \mathrm{~s}^{-2}\right), \rho$ is the air density $\left(\mathrm{kg} \mathrm{m}^{-3}\right), C_{p}$ the air heat capacity $\left(\mathrm{J} \mathrm{kg}^{-1}\right)$, and $T_{\mathrm{a}}$ is the air temperature in ${ }^{\circ} \mathrm{C}$.

The displacement height $(d)$ and the roughness length $\left(z_{0}\right)$ of vegetation are essential parameters for the aerodynamic gradient method. They were estimated by inverting the fluxgradient relationships under neutral conditions for momentum, using $u_{*}$ measured by the eddy covariance method and the wind speeds profile. Formally, $d$ and $z_{0}$ were estimated by linear regression of $z$ against $\exp \left(k U(z) / u_{*}\right)$, where $z_{0}$ is the slope and $d$ is the offset of that linear regression:

$U(z)=\frac{u_{*}}{k} \ln \left(\frac{z-d}{z_{0}}\right) \Rightarrow z=d+z_{0} \cdot \exp \left(\frac{k U(z)}{u_{*}}\right)$

The uncertainty in the $\mathrm{NH}_{3}$ flux due to the uncertainty in the $\mathrm{NH}_{3}$ concentrations (4.4\% of the reading) was estimated by error propagation in Eq. (2). We found that on average the uncertainty on the $\mathrm{NH}_{3}$ flux was $18 \%$ [9\%-43\%] (median [25percentile-75percentile].

\subsection{Footprint analysis and advection error estimations}

In order to estimate the impact of the farm emissions on the flux measurements in the field, a footprint analysis was performed with the Kormann and Meixner (2001) footprint model. The footprint analysis showed that the farm was not influencing much the flux footprint. The local advection error due to the farm at the mast location was also estimated using the FIDES-2D as explained in Loubet et al. (2009). To do so, the farm emission was first inferred with the FIDES2D model in inverse model, using the measured concentrations at the highest level at the mast location and the modeled surface resistances (see Hensen et al. 2009 for a full 


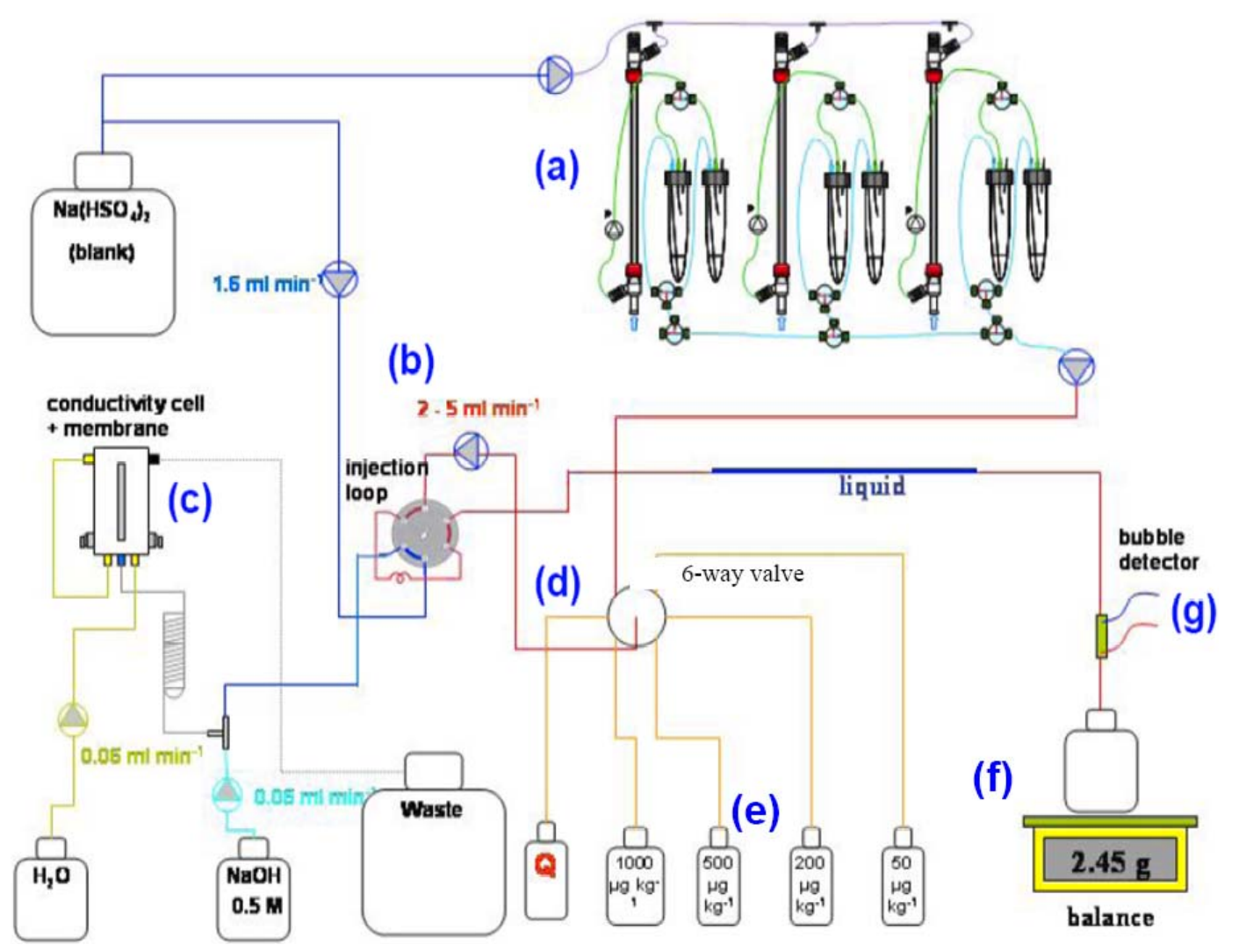

Fig. 2. Scheme of the ROSAA analyser. (a) The three denuders to sample the air and two reservoirs per denuder to store the liquid while analysing. (b) The injection valve to analyse successively the reservoirs and the standards. (c) The ammonium analyser by conductivity and membrane separation. (d) Electro-valves to sample either from the denuder or the standards. (e) The four standards which are sampled every $2 \mathrm{~h}$. (f) the balance to measure the mass of liquid in each reservoir. (g) The bubble detector to control the injection of liquid.

description of the method). The farm emission was eval-

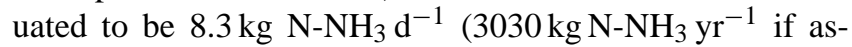
sumed constant over the year). This may be compared with an alternative, bottom-up, estimate: using the emission factors from Gac et al. (2006), $12 \mathrm{~kg} \mathrm{~N}-\mathrm{NH}_{3} \mathrm{yr}^{-1}$ for cows

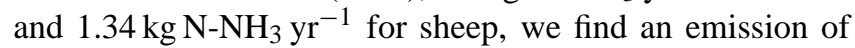
$3900 \mathrm{~kg} \mathrm{~N}-\mathrm{NH}_{3} \mathrm{yr}^{-1}$. Once the farm emission is inferred, we estimated the advection error with the FIDES-2D model following Loubet et al. (2009) as the difference between the flux modeled at the measurement height $\left(d+z_{m}\right.$ and the flux at the canopy top $\left.d+z_{0}\right)$.

\subsection{Inference of canopy ammonia compensation point}

The canopy ammonia compensation point $\left(C_{\mathrm{c}}\right)$ was determined by linear regression between the $\mathrm{NH}_{3}$ flux and the $\mathrm{NH}_{3}$ concentration at $1 \mathrm{~m}$ above displacement height $d$. A moving linear regression over successive $24 \mathrm{~h}$ periods was used. The data were filtered out for dry conditions $(\mathrm{RH}<$ $70 \%$, and $\mathrm{WI}=0$ ). Moreover only $24 \mathrm{~h}$ periods when the flux was both negative and positive were selected, and a supplementary criterion of $R^{2}>0.5$ was used to insure that the regression was consistent. The canopy compensation point
$\left(C_{\mathrm{c}}\right)$ was then simply estimated as the ordinate of the regression of $F_{\mathrm{NH}_{3}}$ against $C_{\mathrm{NH}_{3}}(1 \mathrm{~m})$.

\subsection{Comparison of the measured fluxes with the Surfatm- $\mathrm{NH}_{3}$ model}

The Surfatm- $\mathrm{NH}_{3}$ modelled fluxes (Personne et al., 2009) were compared to the measured fluxes. The soil emission potential $\left(\Gamma_{\mathrm{g}}\right)$ and the cuticular resistance $\left(R_{\mathrm{W}}\right)$ were then empirically tuned to fit the measured data. The Surfatm- $\mathrm{NH}_{3}$ model is a soil-vegetation-atmosphere exchange model coupling the energy balance model of Choudhury and Monteith (1988) with a two-layer resistance analogue model for $\mathrm{NH}_{3}$ transfer similar to that of Nemitz et al. (2001). The Surfatm$\mathrm{NH}_{3}$ model compared well with the $\mathrm{NH}_{3}$ fluxes measured by the aerodynamic gradient method in the 'GRAMINAE Integrated Experiment (Sutton et al., 2009a). Moreover, the model was recently adapted to $\mathrm{O}_{3}$ and tested against $\mathrm{O}_{3}$ fluxes measured by eddy-covariance (Stella et al., 2011).

The Surfatm- $\mathrm{NH}_{3}$ model is described at length in Personne et al. (2009) and is therefore not detailed here. Some changes were introduced in the model parameters to reproduce the conditions encountered during the experiment: 


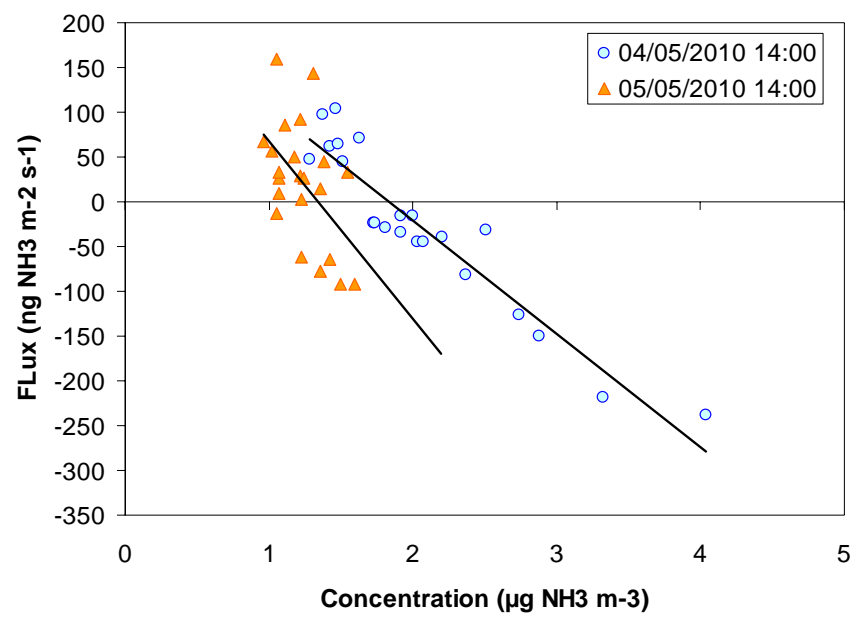

Fig. 3. Illustration of the linear regression method used to obtain the canopy compensation point $\left(C_{\mathrm{c}}\right): C_{\mathrm{c}}$ is the intercept of the linear regression between the measured $\mathrm{NH} 3$ concentration (at $1 \mathrm{~m}$ height) and the NH3 flux. In this case two successive days of data are shown $C_{\mathrm{c}}$ values of 1.8 and $1.3 \mu \mathrm{g} \mathrm{NH} \mathrm{m}^{-3}$.

- The thermal conductivity for wet soil was fixed to $K_{\text {wet }}=1.3 \mathrm{~W} \mathrm{~m}^{-1} \mathrm{~K}^{-1}$ (instead of 1.8 ), the thermal conductivity for dry soil was fixed to $K_{\text {wet }}=0.5$ $\mathrm{W} \mathrm{m} \mathrm{m}^{-1} \mathrm{~K}^{-1}$ (instead of 0.28 ) and $z_{0}$ soil was set to $0.01 \mathrm{~m}$ (instead of 0.2 ).

- The stomatal conductance was modelled with the EMEP approach with a modified parameterisation of spring wheat (Emberson et al., 2000). The modification consisted in changing the minimum temperature of the temperature response function from $12^{\circ} \mathrm{C}$ to $0^{\circ} \mathrm{C}$. The adequacy of this parameterisation was checked by comparing the measured and modelled latent heat flux (LE) which agreed reasonably well $\left(\mathrm{LE}(\right.$ model $)=1.08 \mathrm{LE}($ meas. $\left.)+7.47, r^{2}=0.86\right)$.

- The cuticular resistance $\left(\mathrm{s} \mathrm{m}^{-1}\right)$ was set to $R_{\mathrm{w}}\left(\mathrm{NH}_{3}\right)$ $=0.025 \exp ^{\left\{\left(100-\mathrm{RH}\left(z_{0}\right)\right) / 7\right\}}$, where $\mathrm{RH}\left(z_{0}\right)$ is the relative humidity at $z_{0}(\%)$.

- The soil emission potential $\left(\Gamma_{\mathrm{g}}\right)$ was determined empirically to get the best fit between the measured and the modelled $\mathrm{NH}_{3}$ fluxes.

\section{Results}

\subsection{Micrometeorological conditions}

The experimental campaign showed a large variability in air temperature with a minimum $30 \mathrm{~min}$ average of $1.2^{\circ} \mathrm{C}$ and a maximum of $29.8^{\circ} \mathrm{C}$ and averaged $14.6^{\circ} \mathrm{C}$. The relative humidity ranged from $27 \%$ to $96 \%$ and averaged $71 \%$. The cumulated precipitation was $105 \mathrm{~mm}$ over the period, and was dominated by a rain event from 10 to 12 June. Based on the wetness index, the vegetation was wet $15 \%$ of the time (cumulated time for which WI $=1$ ). Three main rain events occurred: 11 May, 25-26 May and 10-12 June. Overall May was colder than June and two weeks were especially dry and with a clear sky on 18-25 May and 22-29 June, as marked by the large global radiations and wide amplitudes in RH and $T_{\mathrm{a}}$, as well as the rising air temperatures, and northerly wind directions. The soil was rather dry at the start of the experiment (no rain occurred from 12/04 to 01/05), with a surface soil water content of $19 \%$ at $5 \mathrm{~cm}$ depth which reached a minimum of $14 \%$ on $10 / 06$ before increasing to $35 \%$ on $12 / 06$ (following the rain event), before dropping to $15 \%$ at the end of June. The deeper SWC (Soil Water Content) measurement followed the same trend but with a lower magnitude. The wind speed $U$ averaged $1.8 \mathrm{~m} \mathrm{~s}^{-1}$ and ranged from 0 to $6.6 \mathrm{~m} \mathrm{~s}^{-1}$, while $u_{*}$ varied from 0.03 to $0.76 \mathrm{~m} \mathrm{~s}^{-1}$ and averaged $0.25 \mathrm{~m} \mathrm{~s}^{-1}$. The friction velocity $u_{*}$ usually showed a daily pattern with the lowest values at nights and the largest during the day. Windy episodes showing large nightly $u_{*}$ however occurred on $2-5 / 05,28-30 / 05$ and $15-$ 16/06 (Fig. 4).

\subsection{Ammonia concentrations}

The quality control solution used to check the liquid phase measurement of the analyser was within $10 \%$ of the theoretical concentration expected (Fig. 5). On average the difference between the $\mathrm{QC}$ and the measurement was $1.3 \mathrm{ppb} \mathrm{NH}_{4}^{+}$ but with a standard deviation of up to $22 \mathrm{ppb} \mathrm{NH}_{4}^{+}$(the concentrations here are in ppb of $\mathrm{NH}_{4}^{+}$in the acid trapping solution) During periods 27 April-4 May and 6 June-15 June large variations were attributed to observed bubbles in the semi-permeable membrane.

The ammonia concentration at $1 \mathrm{~m}$ above $d$ varied from 0.01 to $39 \mu \mathrm{g} \mathrm{NH} \mathrm{m}^{-3}$ (Fig. 6). The largest daily concentrations were observed between the 01/06 and the 11/06. The concentration averaged over May and June 2010 were 2.0 and $2.5 \mu \mathrm{g} \mathrm{NH} \mathrm{N} \mathrm{m}^{-3}$ with the ROSAA analyser while during the same periods the DELTA denuder measurements gave 3.0 and $2.4 \mu \mathrm{g} \mathrm{NH}_{3} \mathrm{~m}^{-3}$. We should however stress that the gaps in the ROSAA data were not filled which may explain part of the difference in May. There were indeed $15 \%$ of gaps in May and $6 \%$ in June.

The concentration increased clearly when the wind was blowing from the nearby farm. Indeed the red dots in the wind direction plot mostly coincide with concentration peaks measured in the field (Fig. 6). This is even clearer in Fig. 7 where on 29 May and 01 June the concentration increased suddenly when the wind direction was in the farm windsector. The average $\mathrm{NH}_{3}$ concentration was $2.2 \mu \mathrm{g} \mathrm{NH} \mathrm{N}^{-3}$ over the whole period, and averaged $4.5 \mu \mathrm{g} \mathrm{NH} \mathrm{N} \mathrm{m}^{-3}$ when the wind was blowing from the farm. The concentration rose also clearly shows the increased averaged $\mathrm{NH}_{3}$ concentration in the wind sector downwind from the farm. 


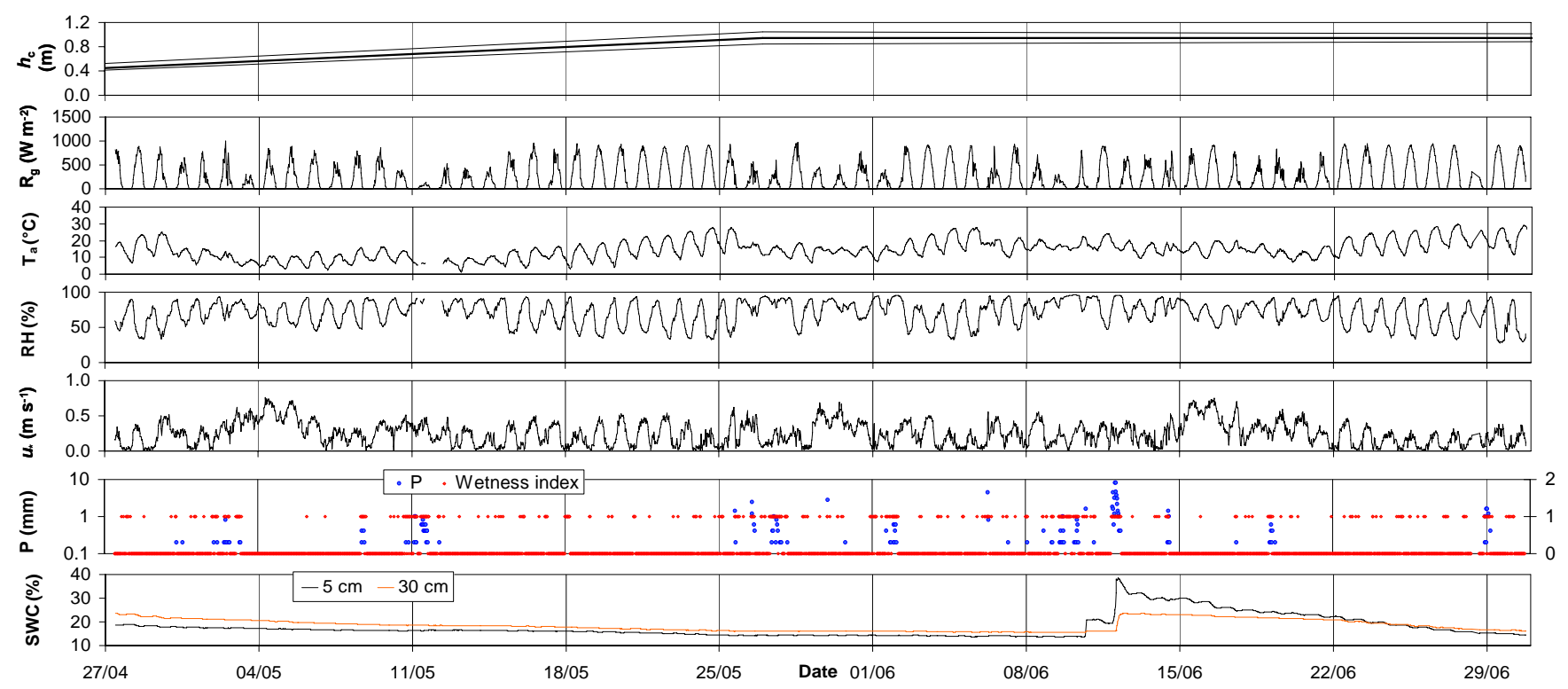

Fig. 4. Canopy height $\left(h_{\mathrm{c}}\right)$ and micrometeorological conditions measured at the site. From top to bottom: canopy height $\left(h_{\mathrm{c}}\right)$, global radiation $\left(R_{\mathrm{g}}\right)$, air temperature $\left(T_{\mathrm{a}}\right)$ and relative humidity at $2 \mathrm{~m}$ above the ground, friction velocity $\left(u_{*}\right)$, precipitation $(P$, left axis), wetness index (right axis), and soil water content (SWC) at 5 and $30 \mathrm{~cm}$ depth. For the canopy height, the mean, minimum and maximum heights are shown.

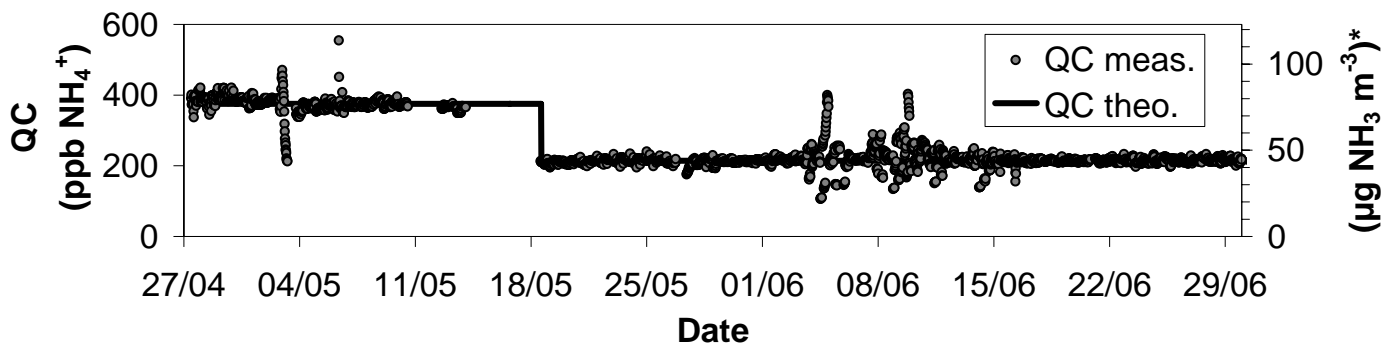

Fig. 5. Measured an theoretical quality control $(\mathrm{QC}) \mathrm{NH}_{4}^{+}$concentration solution throughout the experiment. On average the difference is $1.3 \mathrm{ppb} \mathrm{NH}_{4}^{+}$, with a standard deviation of $22 \mathrm{ppb}$. The relative difference averages $0.6 \%$ with a standard deviation of $8.9 \%$. On the right axis the equivalent atmospheric $\mathrm{NH}_{3}$ concentration is given using the median liquid sampling volume (5.9 ml) and the median air flow rate $\left(1.21 \mathrm{~min}^{-1}\right)$.

\subsection{Ammonia fluxes}

The ammonia flux varied from -560 to $220 \mathrm{ng} \mathrm{NH}_{3} \mathrm{~m}^{-2} \mathrm{~s}^{-1}$ and averaged $-29.3 \mathrm{ng} \mathrm{NH} \mathrm{m}^{-2} \mathrm{~s}^{-1}$, with a median of $-7.7 \mathrm{ng} \mathrm{NH}_{3} \mathrm{~m}^{-2} \mathrm{~s}^{-1}$. For $90 \%$ of the time the flux ranged from -100 to $100 \mathrm{ng} \mathrm{NH}_{3} \mathrm{~m}^{-2} \mathrm{~s}^{-1}$. The largest deposition was observed on $08 / 06$, which was also the period with the largest ammonia concentrations (wind mainly coming from the farm) and relatively wet conditions. Large peaks in $\mathrm{NH}_{3}$ depositions fluxes are also observed around $25 / 5$ and 2629/06. Emissions were mainly observed before $18 / 05$ and during the $15-22 / 06$ period. In the $25 / 05-01 / 06$ and the $08-$ $15 / 06$ periods we clearly observed changes in the sign of the $\mathrm{NH}_{3}$ flux (switching from deposition to emission) when the concentration decreased. This indicated that the exchange was driven by the atmospheric transfer rate and the differ- ence between $\mathrm{NH}_{3}$ concentration in the atmosphere and the compensation point. Finally, it should be noted that both the change in concentration and the switch from deposition to emission, occurring between 10/06 and 12/06, corresponded to the rain event that raised soil water content up to field capacity at the soil surface (Fig. 4).

\subsection{Advection errors and flux footprint}

On average, a flux footprint of $0.02 \%$ originated from the farm. This was merely due to the fact that the farm was located at around $460 \mathrm{~m}$ away from the gradient mast which was located quite close to the ground. The local advection error due to the farm averaged $6.4 \mathrm{ng} \mathrm{NH}_{3} \mathrm{~m}^{-2} \mathrm{~s}^{-1}$ (median $2.7 \mathrm{ng} \mathrm{NH}_{3} \mathrm{~m}^{-2} \mathrm{~s}^{-1}$ ). Moreover, the advection error was found to increase with increasing deposition, which reflects 


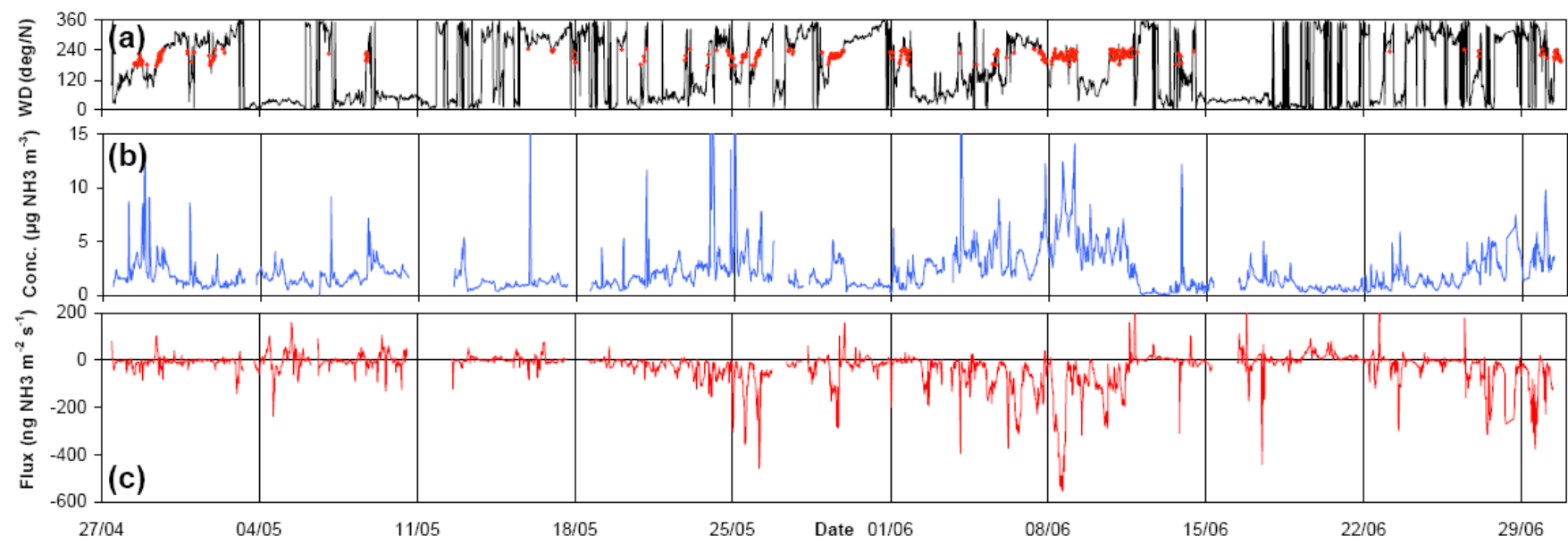

Fig. 6. Wind direction, $\mathrm{NH}_{3}$ concentrations and fluxes: (a) wind direction (WD) (in red dots the periods when the wind was coming from the farm are highlighted), (b) $\mathrm{NH}_{3}$ concentration (Conc.), and (c) fluxes (Flux) at $1 \mathrm{~m}$ above the displacement height $d$.

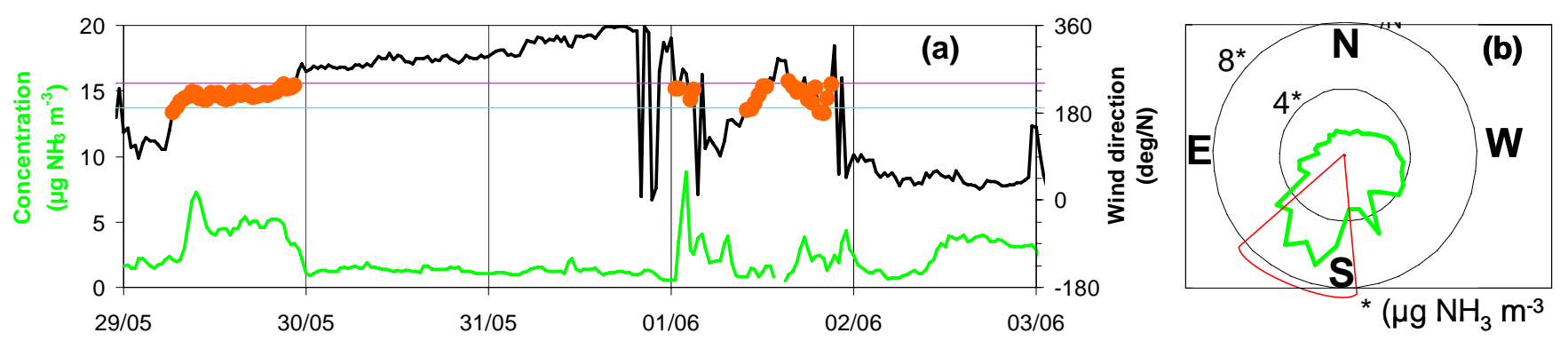

Fig. 7. (a) Example period when the $\mathrm{NH}_{3}$ concentration was enhanced when the wind was blowing from the farm. The purple and Cyan lines show the wind sector where the wind was blowing from the farm. (b) Ammonia concentration rose averaged over the whole period. The wind sector where the wind is blowing from the farm is materialised by the red triangle.

the fact that the deposition increased with increasing atmospheric concentration (itself being influenced by the nearby farm). Overall, the advection error was therefore quite small and represented around $-8 \%$ of the measured flux.

\subsection{Canopy compensation point}

The canopy compensation point $\left(C_{\mathrm{c}}\right)$, determined from the regression between the flux and the concentration, ranged from 0.4 to $3.0 \mu \mathrm{g} \mathrm{NH} \mathrm{N}^{-3}$, and averaged $1.5 \mu \mathrm{g} \mathrm{NH} \mathrm{m}^{-3}$ (Fig. 8) The values of $C_{\mathrm{c}}$ estimated with the linear regression method were of the same magnitude as those inferred from the resistance analogue scheme: $C_{\mathrm{c}}=F_{\mathrm{NH}_{3}} \times$ $\left(R_{a}+R_{b}^{\mathrm{NH}_{3}}\right)+C_{\mathrm{a}}$. There was no clear temporal trend in $C_{\mathrm{c}}$. However, when $C_{\mathrm{c}}$ was normalised by the temperature response function of the effective Henry equilibrium according to the following equation (see Loubet, 2000, $p$ 159); $\Gamma_{\mathrm{c}}=C_{\mathrm{c}} / 10^{-3.4362+0.0508 T_{\mathrm{a}}\left(\left\{^{\circ} \mathrm{C}\right\}\right)}$, a temporal trend appears where the $\Gamma_{\mathrm{c}}$ decreases from around 2000 on $04 / 05$ to $450 \pm 70$ in June (Fig. 8). The jump in $\Gamma_{\mathrm{c}}$ between 28/04 and $04 / 05$ may be related to the $3.2 \mathrm{~mm}$ cumulated rain that occurred on 30/04-03/05, which was the first rainfall occur- ring after the nitrogen solution application on 10/04. On, average $\Gamma_{\mathrm{c}}$ was 950 and varied from 220 to 2200 . The background stomatal $\Gamma_{\mathrm{s}}$ value calculated for the Grignon site according to Massad et al. (2010) accounting for total annual $\mathrm{N}$ input and atmospheric $\mathrm{N}$ deposition is equal to 650. This value is similar to the $\Gamma_{\mathrm{c}}$ obtained in June (once the effect of nitrogen application was no longer felt). Although Massad et al. (2010) $\Gamma_{\mathrm{s}}$ are for stomata, it is within the range of the $\Gamma_{\mathrm{c}}$ calculated from the measurements. Moreover $\Gamma_{\mathrm{c}}$ is lower than the median $\Gamma_{\mathrm{g}}\left(\Gamma_{\mathrm{g}}=2472\right)$ reported by Massad et al. (2010) for arable land.

\subsection{Comparison of the measured fluxes with the Surfatm- $\mathrm{NH}_{3}$ model}

The Surfatm- $\mathrm{NH}_{3}$ model reproduced the measured LE fluxes during the whole experimental campaign very well $\left(\mathrm{LE}(\right.$ model $)=1.08 \mathrm{LE}($ meas. $\left.)+7.47\left(\mathrm{~W} \mathrm{~m}^{-2}\right), r^{2}=0.86\right)$, indicating that the stomatal resistance, the aerodynamic resistances (within the canopy and above) and the boundary layer resistances (soil and plant) were all reasonably well characterised (Fig. 9). However, the Surfatm- $\mathrm{NH}_{3}$ model 


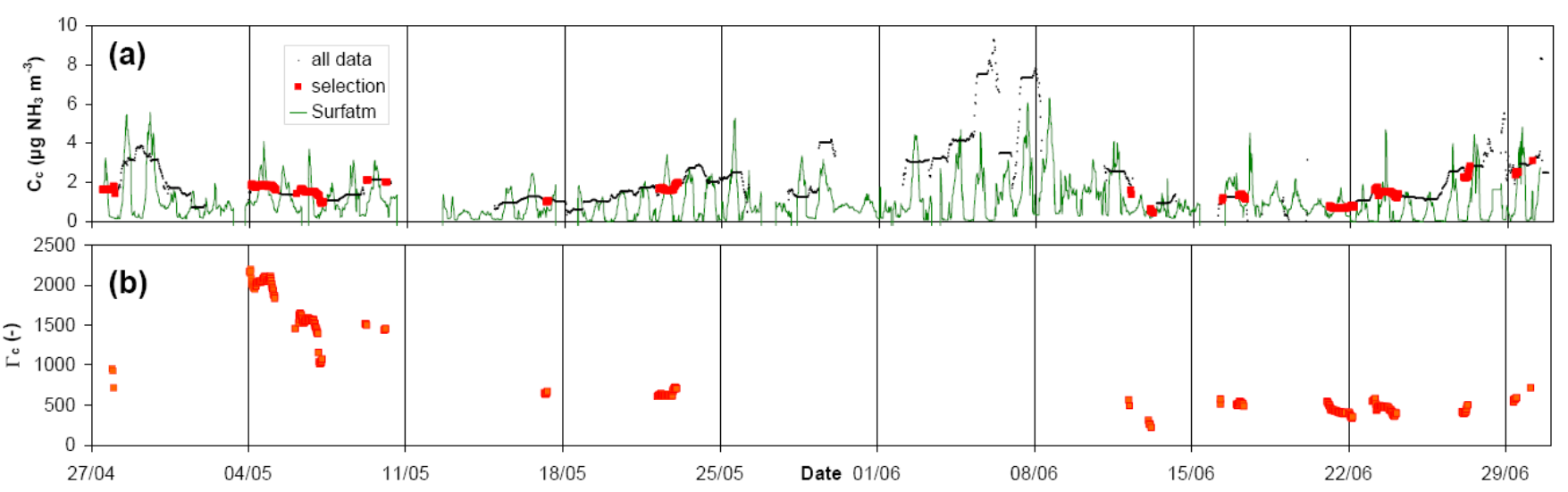

Fig. 8. (a) Canopy compensation point $\left(C_{\mathrm{c}}\right)$ estimated as the offset of the linear regression between the $\mathrm{NH}_{3}$ flux and $\mathrm{NH}_{3}$ concentration over daily periods (black dots). The selection (red dots) represents periods for which the flux was positive and negative over the day and in which the linear regression had an $R^{2}>0.5$. The green line is the canopy compensation point estimated as $C_{\mathrm{c}}=F_{\mathrm{NH}_{3}} \times\left(R_{\mathrm{a}}+R_{\mathrm{b}}^{\mathrm{NH}_{3}}\right)+C_{\mathrm{a}}$. (b) Canopy emission potential estimated as $\Gamma_{\mathrm{c}}=C_{\mathrm{c}} / 10^{-3.4362+0.0508 T_{\mathrm{a}}\left({ }^{\circ} \mathrm{C}\right)}$, which can be viewed as the canopy compensation point normalised by the temperature response of the Henry equilibrium.

tended to overestimate LE when the soil was drier and to underestimate it when the soil was wetter (Figs. 4 and 9), which may be an indication that the sum of canopy aerodynamic, soil boundary layer and soil resistances may be slightly too high, and/or that the temperature and water stress functions of the stomatal resistance may not be well parameterised. Nevertheless, with an average agreement of within $5 \%$ for LE, the parameterisation of Surfatm- $\mathrm{NH}_{3}$ may be considered satisfactory.

With the parameterisation of the soil potential emission $\Gamma_{\mathrm{g}}$, as shown in Fig. 9 (see the discussion section for further information), the dynamics of the simulated flux (and deposition velocity) agreed well with the measurements over the whole period. According to the model, before 11/05, the flux oscillates from deposition to emission under the influence of a quite constant cuticular deposition and a strong emission source, while during the quite dry periods of the 18/05-25/05 and 27/06-30/06, the flux entirely consists in deposition to the leaf cuticle. The $25 / 05-15 / 06$ period is also dominated by deposition to the leaves but with a quite strong emission from the soil. Finally, the 15/06-27/06 period shows the largest emissions from the soil.

Although the parameterisation of the model could account for the observed flux dynamics, the choice of $\Gamma_{\mathrm{g}}$ and $R_{\mathrm{W}}$ $\left(\mathrm{NH}_{3}\right)$ were arbitrary and due to the interactions between these two parameters, it can not be excluded that other parameterisations may work as well. This is therefore further investigated in the discussion (Sect. 4.3).

\section{Discussion}

\subsection{Ammonia fluxes over triticale}

The ammonia concentration measured during the campaign with the ROSAA analyser and the DELTA tubes compared favourably in June but differed in May. The median measured deposition flux $7.7 \mathrm{ng} \mathrm{NH} \mathrm{m}^{-2} \mathrm{~s}^{-1}$ would correspond to $2 \mathrm{~kg} \mathrm{~N}-\mathrm{NH}_{3} \mathrm{ha}^{-1} \mathrm{yr}^{-1}$. This is of the same order as the averaged flux estimated by Flechard et al. (2011), $-2.75 \mathrm{~kg} \mathrm{~N}-\mathrm{NH}_{3} \mathrm{ha}^{-1} \mathrm{yr}^{-1}$ in Grignon over three years, based on the concentration measured with the DELTA tubes and a comparison of four inferential models. The average measured deposition ( $7.6 \mathrm{~kg} \mathrm{~N}-\mathrm{NH}_{3} \mathrm{ha}^{-1} \mathrm{yr}^{-1}$ ) would be larger than the averaged flux estimated by Flechard et al. (2011) but would be similar to the IDEM model estimate $\left(6.2 \mathrm{~kg} \mathrm{~N}-\mathrm{NH}_{3} \mathrm{ha}^{-1} \mathrm{yr}^{-1}\right)$, which is a model without $\mathrm{NH}_{3}$ bi-directional exchange. Using integrated horizontal flux methods, Schjoerring et al. (1993) reported net ammonia emissions over barley plants of around $0.5-1.5 \mathrm{~kg} \mathrm{~N}$ $\mathrm{NH}_{3} \mathrm{ha}^{-1} \mathrm{yr}^{-1}$, while we mainly found deposition here in May and June. They however show that the volatilisation started 2 weeks before anthesis, and peaked about or shortly after anthesis. In our triticale field, anthesis started in the very early June. In another study, Schjoerring and Mattsson (2001) estimated a loss between 1 and $5 \mathrm{~kg} \mathrm{~N}-\mathrm{NH}_{3} \mathrm{ha}^{-1} \mathrm{yr}^{-1}$ by an oilseed rape-wheat-barley-pea rotation. It is however known that the oilseed rape crop leads to large emissions during the senescence (Nemitz et al., 2000). Moreover pea leads to an increased nitrogen uptake by the ecosystem due to $\mathrm{N}$ fixation. Finally these studies include emissions following nitrogen application which dominates the overall fluxes in general. Indeed, the measurements over barley by Schjoerring and Mattsson (2001) show $\mathrm{NH}_{3}$ deposition (of less than 

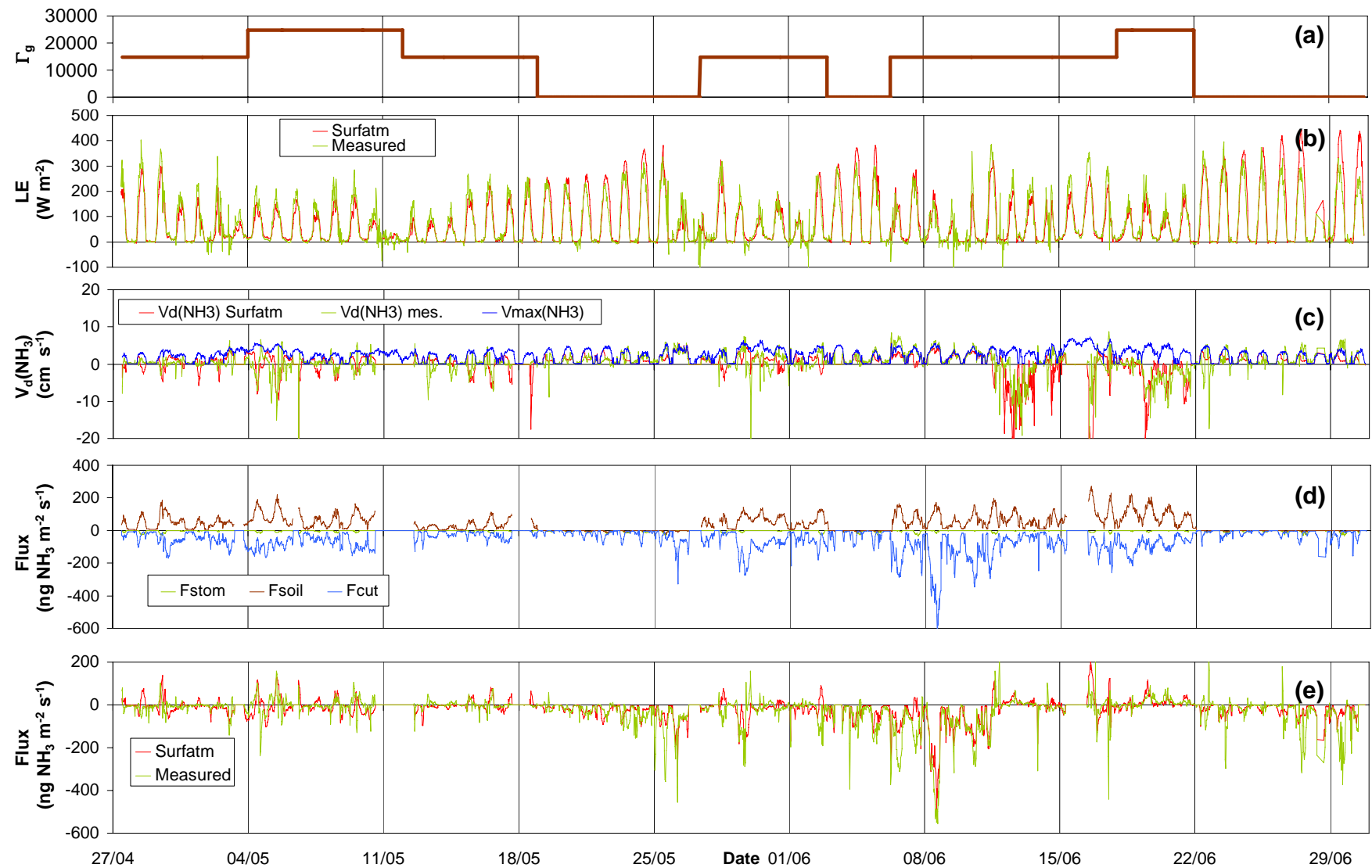

Fig. 9. From top to bottom: (a) soil $\mathrm{NH}_{3}$ emission potential $\left(\Gamma_{\mathrm{g}}\right)$, (b) comparison of simulated and measured latent heat fluxes (LE), (c) $\mathrm{NH}_{3}$ deposition velocity $\left(V_{\mathrm{d}}\right),(\mathbf{d})$ the fluxes form each compartment of the model (soil, stomatal, cuticular), (e) and the total $\mathrm{NH}_{3}$ fluxes (Flux). For comparison the maximum deposition velocity is also given in the $V_{\mathrm{d}}$ graph. Negative deposition velocities correspond to $\mathrm{NH}_{3}$ emissions. In the simulations $\Gamma_{\mathrm{s}}$ was set to zero while the $\Gamma_{\mathrm{g}}$ was empirically set to the values given in the top graph. The $\Gamma$ is the ratio $\left[\mathrm{NH}_{4}^{+}\right] /\left[\mathrm{H}^{+}\right]$in the liquid phase of the given compartment.

$0.5 \mathrm{~kg} \mathrm{~N}-\mathrm{NH}_{3} \mathrm{ha}^{-1}$ in April, May or June). Additionally, the weekly averaged $\mathrm{NH}_{3}$ concentration at $1 \mathrm{~m}$ above displacement height in Schjoerring and Mattsson (2001) was between 1 and $4 \mu \mathrm{g} \mathrm{NH} \mathrm{Nm}^{-3}$ whereas it was up to $5 \mu \mathrm{g} \mathrm{NH} \mathrm{Nm}^{-3}$ during two weeks in our study (01-15/06), emphasising the fact that in our case the flux was strongly influenced by $\mathrm{NH}_{3}$ emissions from the nearby farm.

\subsection{Ammonia emission potential}

The canopy emission potential $\Gamma_{\mathrm{c}}$ (which is a temperature independent compensation point from a thermodynamic perspective) estimated in June $\left(\Gamma_{c}=450 \pm 70\right)$ is close to the median stomatal emission potential reported for managed ecosystems $\left(\Gamma_{\mathrm{s}}=416\right)$ (Massad et al., 2010), although we should point out that most of these data were derived from the same field site, and may therefore not be representative of all conditions. On average, $\Gamma_{\mathrm{c}}=950$ is also close to the mean $\Gamma_{\mathrm{s}}$ (782) reported by Massad et al. (2010) for crops.

Moreover, according to the data compiled by Massad et al. (2010), the maximum emission potential $\Gamma_{\mathrm{c}}=2200$ found around the $04 / 05$ (Fig. 8) is among the largest $\Gamma_{\mathrm{s}}(\max )$ reported for crops but is relatively small when compared to reported ground emission potentials, which varied from 360 to 13000 for non fertilised periods (Massad et al., 2010). Moreover, the ground emission potential $\left(\Gamma_{\mathrm{g}}\right)$ that led to the better fit between Surfatm- $\mathrm{NH}_{3}$ and the measured fluxes ranged from 0 to 25000 (Fig. 9), a value larger than those reported by Massad et al. (2010) for wheat and smaller than $\Gamma_{\mathrm{g}}$ reported following fertilisation.

Wichink Kruit et al. (2010) reported that the stomatal compensation point in a grassland varied seasonally exponentially with surface temperature. If we plot the $\Gamma_{\mathrm{c}}$ as a function of leaf temperature (modelled with Surfatm- $\mathrm{NH}_{3}$ ), we find a similar response with $\Gamma_{\mathrm{c}}$ decreasing exponentially with leaf temperature (Fig. 10). Moreover, the $\Gamma_{\mathrm{c}}$ estimated in this study is within the range of the estimates given by Wichink Kruit et al. (2010). This exponential decrease with temperature may be explained by the correlation between temperature and radiation (and therefore photosynthesis). Indeed when the photosynthetic activity increases ammonium 


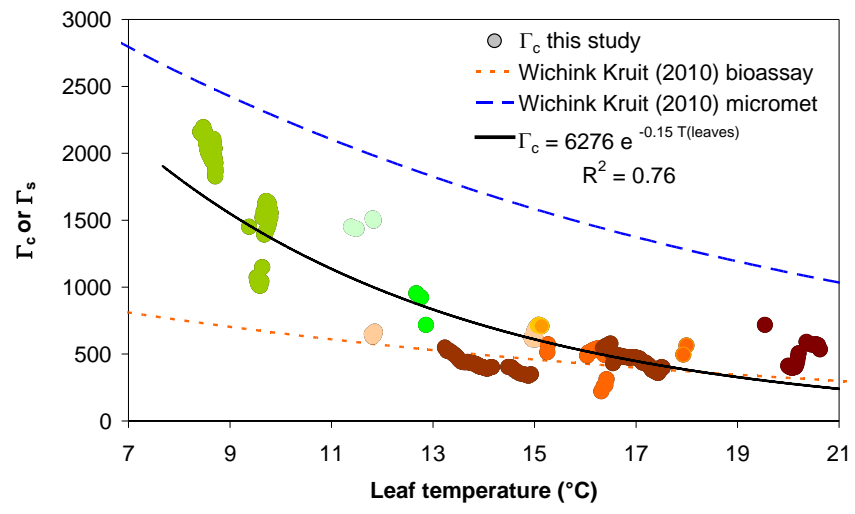

Fig. 10. $\Gamma_{\mathrm{c}}$ as a function or leaf temperature (estimated with Surfatm $\mathrm{NH}_{3}$ ) (rounds). Each color represent a weekly period (from week 18 in brown to week 27 in green) The solid black line is the fitted exponential function and the dotted lines are the modelled $\Gamma_{\mathrm{s}}$ in Wichink et al. (2010) using either the micrometeorogical estimate (blue dotted line) or the bioassay estimate (orange dotted) of $\Gamma_{\mathrm{s}}$. The latter were estimated using the regression lines in Fig. 9

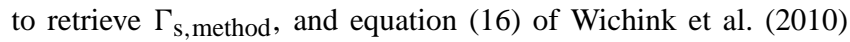
to express the dependency to leaf temperature $\left(\Gamma_{\mathrm{s}}=\Gamma_{\mathrm{s}}\right.$, method $\left.4.7 \times \exp ^{-0.071 \times \mathrm{Ts}}\right)$. The $\Gamma_{\mathrm{s} \text {, method were estimated based on the }}$ average $\mathrm{NH}_{3}$ concentration during the experiment (were 260 for the bioassays and 890 for the micrometeorological estimates.

is effectively used by plant metabolism to form amino acids in the GS/GOGAT cycle (Massad et al., 2008). As a consequence, ammonium is efficiently used by plant.

In this study, it is difficult to determine whether the emission came from the ground or the stomata. However, the emission potentials derived either from the empirical method (linear regression of flux vs. concentration, Fig. 8) or from the rather subjective fitting of the Surfatm- $\mathrm{NH}_{3}$ model are both coherent with the existing literature. Indeed, the field received $40 \mathrm{~kg} \mathrm{~N} \mathrm{ha}^{-1}$ as ammonium-nitrate in a solution on the $10 / 04$. We can assume that this small quantity was quickly absorbed by the growing canopy. The evolution observed in Figure 8 with the sharp increase of $\Gamma_{\mathrm{c}}$ on $04 / 05$ and the subsequent decrease may be explained by the $3.2 \mathrm{~mm}$ rain observed between 30/04 and the 03/05, which had led to a rewetting of the surface (Fig. 4) and a subsequent availability of the ammonium in the liquid phase for ammonia volatilisation. The following re-drying of the surface could explain the lowering of the apparent soil compensation point modelled, due to an increased dry soil resistance and a decreased source of $\mathrm{NH}_{4}^{+}$Fig. 8-top).

\subsection{Sources and sinks of $\mathrm{NH}_{3}$ in the canopy and its parameterisation in Surfatm- $\mathrm{NH}_{3}$}

On the basis of the modelled fluxes we estimate that the soil was a significant source of $\mathrm{NH}_{3}$ leading to an average flux of $44 \mathrm{ng} \mathrm{NH}_{3} \mathrm{~m}^{-2} \mathrm{~s}^{-1}$, while the vegetation was a significant sink leading to $-66 \mathrm{ng} \mathrm{NH}_{3} \mathrm{~m}^{-2} \mathrm{~s}^{-1}$. The averaged net flux modelled above the triticale was $-22 \mathrm{ng} \mathrm{NH}_{3} \mathrm{~m}^{-2} \mathrm{~s}^{-1}$. However, one of the main difficulties in parameterising the $\mathrm{NH}_{3}$ flux in Surfatm- $\mathrm{NH}_{3}$ is the interactions between the cuticular, soil and stomatal pathways. This leads to the non-uniqueness of a given parameterisation that fits the measured flux. An additional difficulty comes from the dynamics of the stomatal and soil compensation points and the cuticular resistance, the first two being dependent on management, soil wetness or plant metabolism while the last depends upon the load of acids on the leaves and the surface wetness (Flechard et al., 2011; Massad et al., 2010). The stomatal resistance is less of a problem since the comparison between measured and modelled water vapour flux gives the opportunity to check or even fit the stomatal resistance model. In this study the stomatal resistance was modelled according to EMEP for spring wheat (Emberson et al., 2000) modified with respect to the minimal temperature in the temperature response function. This parameterisation was considered appropriate based on the agreement between measured and modelled LE (see Fig. 9).

Regarding the cuticular and ground pathways, we used the parameterisation of Personne et al. (2009) for $R_{\mathrm{w}}$ which has a similar relationship with RH to what is used in the CBED and EMEP models (Flechard et al., 2011). The minimal cuticular resistance was adjusted to reproduce the largest deposition flux which occurred between the 22/05 and the 11/06 (Fig. 8) and was thus equal to $R_{\mathrm{w}}^{\min }=0.025 \mathrm{~s} \mathrm{~m}^{-1}$ (an $R_{\mathrm{w}}$ set to 0 or 1 would not give a fit as good as this one over the whole period). Then, in order to minimise the number of parameters to adjust, and since the cuticular resistance was very small, the soil emission potential $\left(\Gamma_{\mathrm{g}}\right)$ was adjusted over weekly periods to fit the observed $\mathrm{NH}_{3}$ flux. The result is reasonable in terms of net flux (Fig. 9), but the question still arises as to whether this parameterisation is plausible and is the only valid one.

To explore this parameterisation further, we conducted a short sensitivity study with the Surfatm- $\mathrm{NH}_{3}$ model (Fig. 11). It can be seen that most of the $\mathrm{NH}_{3}$ flux dynamics can be explained by setting $R_{\mathrm{W}}=0$ during the period $18 / 05$ to the $15 / 06$ and after the $22 / 06$. This parameterisation is equivalent to a simple big leaf model with a zero surface resistance and a zero compensation point. It can also be seen that the very small surface resistance can be approached with the EMEP-03 model (Flechard et al., 2011) with a 5 ppb SO 2 concentration. Monthly $\mathrm{SO}_{2}, \mathrm{HNO}_{3}$ and $\mathrm{HCl}$ concentrations were measured with the Delta tubes during this experiment: the $\mathrm{SO}_{2}, \mathrm{HNO}_{3}$ and $\mathrm{HCl}$ concentrations averaged $0.29,0.69$ and $0.1 \mathrm{ppb}$. In 2008 half hourly $\mathrm{SO}_{2}$ concentrations were measured and showed a large variability with maximums up to $35 \mathrm{ppb}$ and concentration almost daily reaching $2 \mathrm{ppb}$. These large $\mathrm{SO}_{2}$ concentrations are due to the vicinity of large power plants to the North a few tens of kilometres away, and to an incinerator $1 \mathrm{~km}$ to the West emitting $8.5 \times 10^{3} \mathrm{~kg} \mathrm{SO}_{2} \mathrm{yr}^{-1}$. In the Yvelines district, $20 \mathrm{~km}$ due West of Central Paris, the $\mathrm{SO}_{2}$ emissions are $6.6 \times 10^{6} \mathrm{~kg} \mathrm{SO}_{2} \mathrm{yr}^{-1}\left(2.9 \times 10^{3} \mathrm{~kg} \mathrm{SO}_{2} \mathrm{~km}^{-2} \mathrm{yr}^{-1}\right) 80 \%$ 


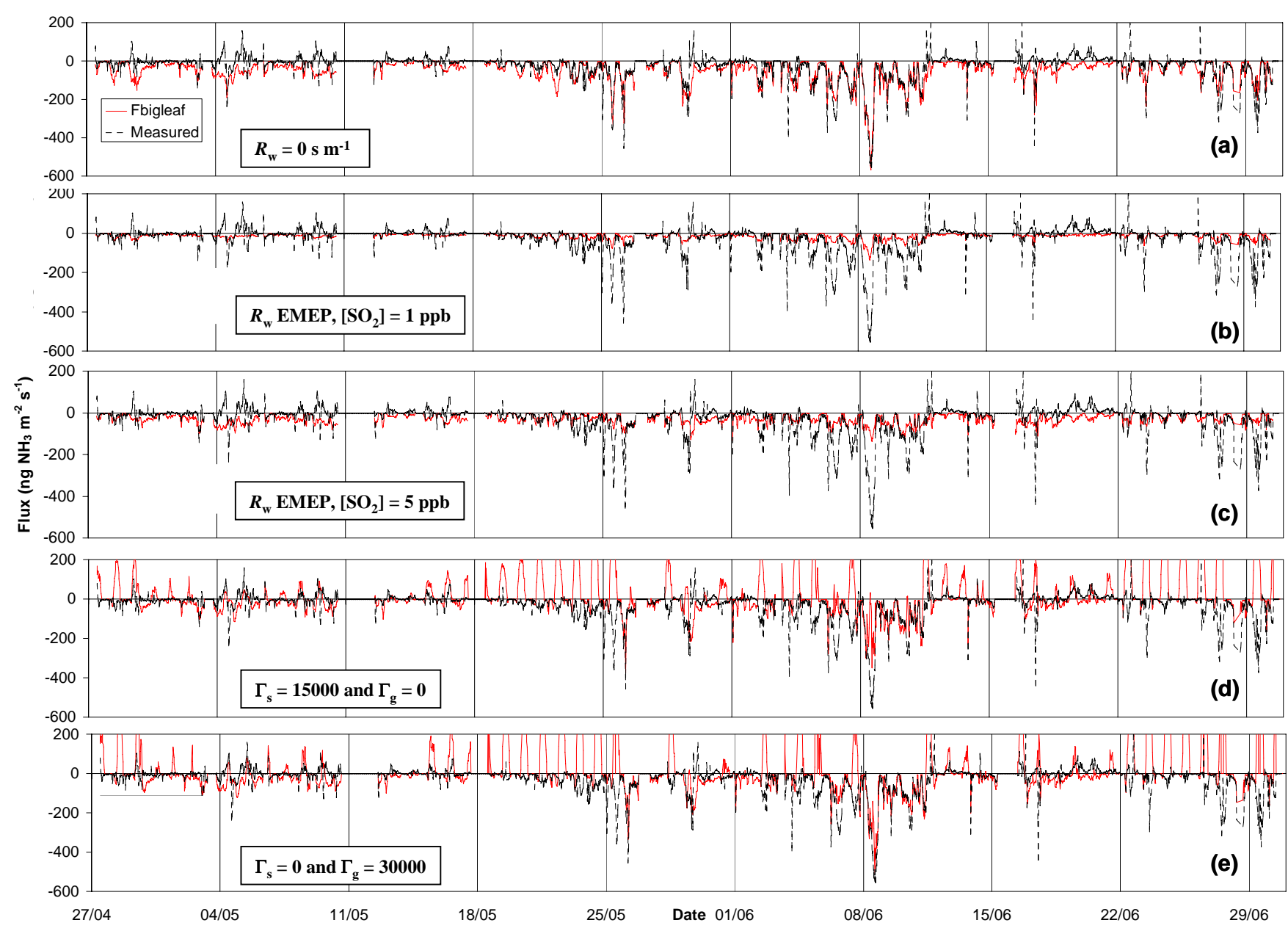

Fig. 11. Sensitivity analysis of the Surfatm- $\mathrm{NH}_{3}$ model to the cuticular resistance, the soil $\left(\Gamma_{\mathrm{g}}\right)$ and stomatal $\left(\Gamma_{\mathrm{S}}\right)$ emission potentials. From top to bottom: (a) $R_{\mathrm{W}}=0 \mathrm{~s} \mathrm{~m}^{-1}$, (b) $R_{\mathrm{W}}$ from EMEP-03 with $\left[\mathrm{SO}_{2}\right]=1 \mathrm{ppb}$, (c) $R_{\mathrm{W}}$ from EMEP-03 with $\left[\mathrm{SO}_{2}\right]=5 \mathrm{ppb}$, (d) $R_{\mathrm{W}}$ fitted and $\Gamma_{\mathrm{S}}=15000$ and $\Gamma_{\mathrm{g}}=0$, (e) $R_{\mathrm{W}}$ fitted and $\Gamma_{\mathrm{s}}=0$ and $\Gamma_{\mathrm{g}}=30000$. If not otherwise stated, $R_{\mathrm{W}}($ fitted $)=0.025 \exp \left(\left(100-\mathrm{RH}\left(z_{0}\right)\right) / 7\right)$ and $\Gamma_{\mathrm{s}}=\Gamma_{\mathrm{g}}=0$.

of which is due to power plants (AIRPARIF). Moreover the site is also exposed to quite high $\mathrm{HNO}_{3}$ concentrations which range from 0.7 and $3 \mathrm{ppb}$ (Loubet et al., 2011) and averaged $0.69 \mathrm{ppb}$ during the experiment. The concentration in total gaseous acids at the site was $1.33 \mathrm{ppb}$ during the experiment while the $\mathrm{NH}_{3}$ concentration was $3.6 \mathrm{ppb}$ (according to the Delta measurements). The ratio of acids to $\mathrm{NH}_{3}$ concentration would not be sufficient to justify (based on the EMEP-03 approach) the small minimum cuticular resistance we found here (Massad et al., 2010). Additional acid deposition has to have occurred to explain the measured cuticular resistance.

Two deposition episodes (18/05-26/05 and 02/06-11/06) ended with a sharp change from deposition-dominated patterns to clearly bi-directional exchange, which was concomitant with a rain event. This could be interpreted in at least four ways: (1) the rain event is correlated to a lowering of the atmospheric concentration (rain out and/or change in wind direction associated with change in weather), which in virtue of the given canopy compensation point leads to emissions; or (2) the rain event washed the leaves which lose their acidic load leading to a dramatic increase of the cuticular resistance which in turns leads to a lowered leaf deposition and thus a net emission. However, we should consider that rain is also generally acidic; or (3) the rain event leads to an increase in the ground or stomatal compensation point due to increased availability of the $\mathrm{NH}_{4}^{+}$ions in the soil; or (4) the deposited $\mathrm{NH}_{4}^{+}$was emitted back from the surface. All four interpretations are plausible. It is however difficult to disentangle which of the four explanations, or which combination of these, has occurred. Indeed, in Fig. 11 one can see that both stomatal and ground compensation points may explain the emissions episodes (top two graphs). These graphs however show that at least one of the two emission potentials $\left(\Gamma_{\mathrm{g}}\right.$ or $\Gamma_{\mathrm{s}}$ ) must have changed throughout the period, otherwisen large emission would have been observed during the 18/05$22 / 05$ or the $22 / 06-30 / 06$ periods. It is also likely that a 
higher cuticular resistance and a much lower compensation point (either ground or stomatal) could explain the observed emission periods.

\section{Conclusions}

The ROSAA analyser proved to be suitable for measuring ammonia concentrations and estimating surface/atmosphere exchange of ammonia in background conditions. The measured ammonia concentrations varied from 0.01 to $39 \mu \mathrm{g} \mathrm{NH} \mathrm{N} \mathrm{m}^{-3}$ and were largely influenced by advection from a nearby farm. On average the concentrations were 2.0 and $2.5 \mu \mathrm{g} \mathrm{NH} \mathrm{m}^{-3}$ in May and June and compared favourably with the concentrations measured with a reference DELTA system in June but differ significantly in May.

The ammonia fluxes ranged from -560 to $220 \mathrm{ng} \mathrm{NH} \mathrm{N}^{-2} \mathrm{~s}^{-1}$ and averaged $-29 \mathrm{ng} \mathrm{NH} 3 \mathrm{~m}^{-2} \mathrm{~s}^{-1}$ over the measurement period. During three to four weeks the deposition fluxes were large and could only be explained by a surface resistance close to zero. This small surface resistance can partly be explained by the quite heavy load of acid gases $\left(\mathrm{HNO}_{3}\right.$ and $\left.\mathrm{SO}_{2}\right)$ in this area. This is due to the measurement site being in the plume of power plants to the North, a nearby incinerator to the West emitting large quantities of $\mathrm{SO}_{2}$, as well as the contribution to acidic load from heavy road traffic in the area. These measurements are in contrast with the existing literature, which report emissions from wheat or barley during anthesis.

Ammonia emissions were also measured occasionally, indicating a canopy compensation point averaging $1.5 \mu \mathrm{g} \mathrm{NH} \mathrm{Nm}^{-3}$ and ranging from 0.4 to $3.0 \mu \mathrm{g} \mathrm{NH}_{3} \mathrm{~m}^{-3}$. When normalised by the temperature response of the Henry equilibrium for $\mathrm{NH}_{3}$, the resulting canopy emission potential $\left(\Gamma_{\mathrm{c}}\right)$ was found to decrease from $\Gamma_{\mathrm{c}}=2200$ at the start of the experiment to $\Gamma_{\mathrm{c}}=450 \pm 70$ in June, a value close to the median $\Gamma_{\mathrm{s}}$ for managed ecosystems. The observed decrease in $\Gamma_{\mathrm{c}}$ may be explained by the transformation and volatilisation of the applied $\mathrm{N}$ following the precipitation occurring at the start of the experiment.

The $\mathrm{NH}_{3}$ fluxes compared well with $\mathrm{NH}_{3}$ fluxes modelled with the Surfatm- $\mathrm{NH}_{3}$ model, in which the minimal cuticular resistance was fitted for the whole period and the soil compensation point was adjusted every week. One difficulty identified in this comparison is the non-uniqueness of the combination of parameters that best fit the $\mathrm{NH}_{3}$ fluxes. This has especially strong consequences on the interpretation of the measured fluxes: it is difficult to determine whether the soil or the stomata are the main sources. Additional measurements of $\mathrm{NH}_{4}^{+}$and $\mathrm{pH}$ of the soil surface, the leaves and the leaves surfaces should be performed in the future to help partition $\mathrm{NH}_{3}$ fluxes.
Acknowledgements. This study was financed by NitroEurope IP (EU) , Vulnoz (ANR, Fr), R2DS (CNRS, Région Ile de France, Fr), Photona (CNRS-INSU, Fr-De), Accent (EU), ESF-NinE (EU). We gratefully acknowledge Bernard de Françu, Dominique Tristan, Jean-Pierre de Saint-Stéban and all the personnel of the "Ferme agronomique de Grignon", for allowing access to their fields.

Edited by: E. Nemitz

\section{References}

Adams, P. J., Seinfeld, J. H., Koch, D., Micley, L., and Jacob, D.: General circulation assessment of direct radiative forcing by the sulfate-nitrate-ammonium-water inorganic aerosol system, J. Geophys. Res., 106, 1097-1111, 2001.

Asman, W. A. H.: Modelling the atmospheric transport and deposition of ammonia and ammonium: an overview with special reference to Denmark, Atmos. Environ., 35, 1969-1983 doi:10.1016/S1352-2310(00)00548-3, 2001.

Aubinet, M., Grelle, A., Ibrom, A., Rannik, U., Moncrieff, J., Foken, T., Kowalski, A.S., Martin, P.H., Berbigier, P., Bernhofer, C., Clement, R., Elbers, J., Granier, A., Grunwald, T., Morgenstern, K., Pilegaard, K., Rebmann, C., Snijders, W., Valentini, R., and Vesala, T.: Estimates of the annual net carbon and water exchange of forests: the EUROFLUX methodology, Adv. Ecol. Res., 30, 113-175, 2000.

Bouwman, A. F., Lee, D. S., Asman, W. A. H., Dentener, F. J., van der Hoek, K. W., and J. G. J. O.: A global high-resolution emission inventory for ammonia, Glob. Biogeochem. Cy., 11, 561587, 1997.

Bussink, D. W. and Oenema, O.: Ammonia volatilization from dairy farming systems in temperate areas: a review, Nutr. Cycl. Agroecosys., 51, 1352-2310, 1998.

Choudhury, B. J. and Monteith, J. L.: A four-layer model for the heat budget of homogeneous land surfaces, Quart. J. Roy. Meteorol. Soc., 114, 373-398, 1988.

Dammgen, U., Erisman, J. W., Cape, J. N., Grunhage, L., and Fowler, D.: Practical considerations for addressing uncertainties in monitoring bulk deposition, Environ. Poll., 134, 535-548, 2005.

De Schrijver, A., Verheyen, K., Mertens, J., Staelens, J., Wuyts, K., and Muys, B.: Nitrogen saturation and net ecosystem production, Nature, 451, 7180, E1-E1, 2008.

de Vries, W., Solberg, S., Dobbertin, M., Sterba, H., Laubhahn, D., Reinds, G. J., Nabuurs, G.-J., Gundersen, P., and Sutton, M. A.: Ecologically implausible carbon response?, Nature, 451, 7180, E1-E3, 2008.

Dentener, F. J. and Crutzen, P. J.: A three-dimensional model of the global ammonia cycle, J. Atmos. Chem., 19, 331-369, 1994.

Emberson, L. D., Ashmore, M. R., Cambridge, H. M., Simpson, D., and Tuovinen, J. P.: Modelling stomatal ozone flux across Europe, Environ. Poll., 109, 403-413 doi:10.1016/S02697491(00)00043-9, 2000.

Eriksson, E.: Composition of atmospheric precipitation, A. Nitrogen compounds, Tellus, 4, 215-232, 1952.

Erisman, J. W., Mennen, M., Hogenkamp, J., Kemkers, E., Goedhart, D., Pul, A. v., Draaijers, G., Duyzer, J., and Wyers, P.: Dry deposition monitoring of $\mathrm{SO}_{2}, \mathrm{NH}_{3}$ and $\mathrm{NO}_{2}$ over a conif- 
erous forest, Biosphere-atmosphere exchange of pollutants and trace substances: experimental and theoretical studies of biogenic emissions and of pollutant deposition, 1997.

Erisman, J. W. and Sutton, M. A.: Reduced nitrogen in ecology and the environment: Special issue of the ESF-FWF Conference in partnership with LFUI, October 2006, Environ. Poll., 154, 357$358,2008$.

Erisman, J. W. and Wyers, P.: Continuous measurements of surface exchange of $\mathrm{SO}_{2}$ and $\mathrm{NH}_{3}$; Inplications for their possible interactions process, Atmos. Environ., 27, 1937-1949, 1993.

Fangmeier, A., Hadwiger-Fangmeier, A., Van der Eerden, L., and Jager, H.-J.: Effects of atmospheric ammonia on vegetation-A review, Environ. Poll., 86, 43-82, 1994.

Farquhar, G. D., Firth, P. M., Wetselaar, R., and Weir, B.: On the gaseous exchange of ammonia between leaves and the environment: determination of the ammonia compensation point, Plant Physiol., 66, 710-714, 1980.

Flechard, C., Fowler, D., Sutton, M. A., and Cap, J. N.: A dynamic chemical model of bi-directional ammonia exchange between semi-natural vegetation and the atmosphere, Quart. J. Roy. Meteorol. Soc., 125, 124-226, 1999.

Flechard, C. R. and Fowler, D.: Atmospheric ammonia at a moorland site. I: The meteorological control of ambient ammonia concentrations and the influence of local sources, Quart. J. Roy. Meteorol. Soc., 124, 733-757, 1998a.

Flechard, C. R. and Fowler, D.: Atmospheric ammonia at a moorland site. II: Long-term surface-atmosphere micrometeorological flux measurements, Quart. J. Roy. Meteorol. Soc., 124, 759-791, 1998b.

Flechard, C. R., Fowler, D., Sutton, M. A., and Cape, J. N.: A dynamic chemical model of bi-directional ammonia exchange between semi-natural vegetation and the atmosphere, Quart. J. Roy. Meteorol. Soc., 125, 2611-2641, 1999.

Flechard, C. R., Nemitz, E., Smith, R. I., Fowler, D., Vermeulen, A. T., Bleeker, A., Erisman, J. W., Simpson, D., Zhang, L., Tang, Y. S., and Sutton, M. A.: Dry deposition of reactive nitrogen to European ecosystems: a comparison of inferential models across the NitroEurope network, Atmos. Chem. Phys., 11, 2703-2728, doi:10.5194/acp-11-2703-2011, 2011.

Flechard, C. R., Spirig, C., Neftel, A., and Ammann, C.: The annual ammonia budget of fertilised cut grassland - Part 2: Seasonal variations and compensation point modeling, Biogeosciences, 7, 537-556, doi:10.5194/bg-7-537-2010, 2010.

Fowler, D., Pilegaard, K., Sutton, M. A., Ambus, P., Raivonen, M., Duyzer, J., Simpson, D., Fagerli, H., Fuzzi, S., Schjoerring, J. K., Granier, C., Neftel, A., Isaksen, I. S. A., Laj, P., Maione, M., Monks, P.S., Burkhardt, J., Daemmgen, U., Neirynck, J., Personne, E., Wichink Kruit, R., Butterbach-Bahl, K., Flechard, C., Tuovinen, J.P., Coyle, M., Gerosa, G., Loubet, B., Altimir, N., Gruenhage, L., Ammann, C., Cieslik, S., Paoletti, E., Mikkelsen, T. N., Ro-Poulsen, H., Cellier, P., Cape, J. N., Horváth, L., Loreto, F., Niinemets, Ü., Palmer, P.I., Rinne, J., Misztal, P., Nemitz, E., Nilsson, D., Pryor, S., Gallagher, M. W., Vesala, T., Skiba, U., Brüggemann, N., Zechmeister-Boltenstern, S., Williams, J., O'Dowd, C., Facchini, M. C., de Leeuw, G., Flossman, A., Chaumerliac, N., and Erisman, J. W.: Atmospheric composition change: Ecosystems-Atmosphere interactions, Atmos. Environ., 43, 5193-5267, 2009.
Gac, A., Béline, F., and Bioteau, T.: Flux de gaz à effet de serre $\left(\mathrm{CH}_{4}, \mathrm{~N}_{2} \mathrm{O}\right)$ et d"ammoniac liés à la gestion des déjections animales: Synthèse bibliographique et élaboration d"une base de données, (CEMAGREF), 80 pp., 2006.

Galloway, J. N., Townsend, A. R., Erisman, J. W., Bekunda, M., Cai, Z. C., Freney, J. R., Martinelli, L. A., Seitzinger, S. P., and Sutton, M. A.: Transformation of the nitrogen cycle: Recent trends, questions, and potential solutions, Science, 320, 889892, 2008.

Génermont, S. and Cellier, P.: A mechanistic model for estimating ammonia volatilization from slurry applied to bare soil, Agr. Forest Meteorol., 88, 145-167, 1997.

Génermont, S., Cellier, P., Flura, D., Morvan, T., and Laville, P.: Measuring ammonia fluxes after slurry spreading under actual field conditions, Atmos. Environ., 32, 279-284, 1998.

Hensen, A., Loubet, B., Mosquera, J., van den Bulk, W. C. M., Erisman, J. W., Dämmgen, U., Milford, C., Löpmeier, F. J., Cellier, P., Mikuška, P., and Sutton, M. A.: Estimation of $\mathrm{NH}_{3}$ emissions from a naturally ventilated livestock farm using local-scale atmospheric dispersion modelling, Biogeosciences, 6, 2847-2860, doi:10.5194/bg-6-2847-2009, 2009.

Houghton, J. T., Ding, Y., Griggs, D. J., Noguer, M., van der Linden, P. J., Dai, X., Maskell, K., and Johnson, C. A.: Climate Change 2001: The Scientific Basis. Contribution of Working Group I to the Third Assessment Report of the Intergovernmental Panel on Climate Change (IPCC), 2001.

Howard, J. B. and Rees, D. C.: Structural basis of biological nitrogen fixation, Chem. Rev., 96, 2965-2982, 1996.

Krupa, S. V.: Effects of atmospheric ammonia $\left(\mathrm{NH}_{3}\right)$ on terrestrial vegetation: a review, Environ. Poll., 124, 179-221, 2003.

Loubet, B., Milford, C., Hensen, A., Daemmgen, U., Erisman, J.W., Cellier, P., and Sutton, M. A.: Advection of $\mathrm{NH}_{3}$ over a pasture field and its effect on gradient flux measurements, Biogeosciences, 6, 1295-1309, doi:10.5194/bg-6-1295-2009, 2009.

Loubet, B., Asman, W. A. H., Theobald, M. R., Hertel, O., Tang, Y. S., Robin, P., Hassouna, M., Dammgen, U., Genermont, S., Cellier, P., and Sutton, M. A.: Ammonia Deposition Near Hot Spots: Processes, Models and Monitoring Methods. Atmospheric Ammonia, Springer Netherland, 205-267, 2009.

Loubet, B., Génermont, S., Ferrara, R., Bedos, C., Decuq, C., Personne, E., Fanucci, O., Durand, B., Rana, G., and Cellier, P.: An inverse model to estimate ammonia emissions from fields, Europ. J. Soil Sci., 61, 793-805, 2010.

Loubet, B., Laville, P., Lehuger, S., Larmanou, E., Flechard, C., Mascher, N., Génermont, S., Roche, R., Ferrara, R.M., Stella, P., Personne, E., Durand, B., Decuq, C., Flura, D., Masson, S., Fanucci, O., Rampon, J.-N., Siemens, J., Kindler, R., Schrumpf, M., Gabriele, B. and Cellier, P.: Carbon, nitrogen and Greenhouse gases budgets over a four years crop rotation In northern France, Plant Soil, 343, 109-137, 2011.

MacDonald, J. A., Skiba, U., Sheppard, L. J., Ball, B., and Roberts, J. D.: The effect of nitrogen deposition and seasonal variability on methane oxidation and nitrous oxide emission rates in an upland spruce plantation and moorland, Atmos. Environ., 31, 3693-3706, 1997.

Magnani, F., Mencuccini, M., Borghetti, M., Berbigier, P., Berninger, F., Delzon, S., Grelle, A., Hari, P., Jarvis, P.G., Kolari, P., Kowalski, A.S., Lankreijer, H., Law, B.E., Lindroth, A., Loustau, D., Manca, G., Moncrieff, J.B., Rayment, M., Tedeschi, 
V., Valentini, R. and Grace, J.: The human footprint in the carbon cycle of temperate and boreal forests, Nature, 447, 849-851, 2007.

Massad, R. S., Loubet, B., Tuzet, A., and Cellier, P.: Relationship between ammonia stomatal compensation point and nitrogen metabolism in arable crops: Current status of knowledge and potential modelling approaches, Environ. Poll., 154, 390403, 2008.

Massad, R.-S., Nemitz, E., and Sutton, M. A.: Review and parameterisation of bi-directional ammonia exchange between vegetation and the atmosphere, Atmos. Chem. Phys., 10, 10359-10386, doi:10.5194/acp-10-10359-2010, 2010.

Melillo, J. M., Steudler, P. A., Aber, J. D., and Bowden, R. D.: Atmospheric deposition and nutrient cycling, edited by: Andreae, M. O. and Schimel, D. S., Exchange of trace gases between terrestrial ecosystems and the atmosphere, Wiley-Interscience, New-York, 263-280, 1989.

Milford, C., Theobald, M. R., Nemitz, E., Hargreaves, K. J., Horvath, L., R aso, J., Dämmgen, U., Neftel, A., Jones, S. K., Hensen, A., Loubet, B., Cellier, P., and Sutton, M. A.: Ammonia fluxes in relation to cutting and fertilization of an intensively managed grassland derived from an inter-comparison of gradient measurements, Biogeosciences, 6, 819-834, doi:10.5194/bg-6819-2009, 2009.

Misselbrook, T. H., Van Der Weerden, T. J., Pain, B. F., Jarvis, S. C., Chambers, B. J., Smith, K. A., Phillips, V. R., and Demmers, T. G. M.: Ammonia emission factors for UK agriculture, Atmos. Environ., 871-880, 2000.

Neftel, A., Blatter, A., Gut, A., Hogger, D., Meixner, F., Ammann, C., and Nathaus, F. J.: $\mathrm{NH}_{3}$ soil and soil surface gas measurements in a triticale wheat field, Atmos. Environ., 32, 499-505, 1998.

Nemitz, E., Milford, C., and Sutton, M. A.: A two-layer canopy compensation point model for describing bi-directional biosphere-atmosphere exchange of ammonia, Quart. J. Roy. Meteorol. Soc., 127, 815-833, 2001.

Nemitz, E., Sutton, M. A., Gut, A., San Jose, R., Husted, S., and Schjørring, J. K.: Sources and sinks of ammonia within an oilseed rape canopy, Agr. Forest Meteorol., 105, 385-404, 2000.

Personne, E., Loubet, B., Herrmann, B., Mattsson, M., Schjoerring, J. K., Nemitz, E., Sutton, M. A., and Cellier, P.: SURFATMNH3: a model combining the surface energy balance and bidirectional exchanges of ammonia applied at the field scale, Biogeosciences, 6, 1371-1388, doi:10.5194/bg-6-1371-2009, 2009.

Schjoerring, J. K., Kyllingsbaek, A., Mortensen, J. V., and Byskovnielsen, S.: Field investigations of ammonia exchange between barley plants and the atmosphere, 1 . Concentration profiles and flux densities of ammonia, Plant Cell Environ., 16, 161$167,1993$.

Schjoerring, J. K. and Mattsson, M.: Quantification of ammonia exchange between agricultural cropland and the atmosphere: measurements over two complete growth cycles of oilseed rape, wheat, barley and pea, Plant Soil, 228, 105-115, doi:10.1023/A:1004851001342, 2001.

Simpson, D., Fagerli, H., Jonson, J. E., Tsyro, S., Wind, P., and Tuovinen, J.-P.: Transboundary Acidification, Eutrophication and Ground Level Ozone in Europe, Part I: Unified EMEP Model Description, EMEP Status Report 2003, ISSN 0806-4520, Det Meteorologisk Institutt, Oslo, 2003.
Sommer, S. G., Genermont, S., Cellier, P., Hutchings, N. J., Olesen, J. E., and Morvan, T.: Processes controlling ammonia emission from livestock slurry in the field, Europ. J. Agronomy, 19, 465486, 2003.

Stella, P., Loubet, B., Lamaud, E., Laville, P., and Cellier, P.: Ozone deposition onto bare soil: a new parameterisation, Agr. Forest Meteorol., 151, 669-681, 2011.

Sutton, M. A., Burkhardt, J. K., Guerin, D., and Fowler, D.: Measurement and modelling of ammonia exchange over arable croplands, edited by: Heij, G. J. and Erisman, J. W., Acid rain research, Do we have enough answers? Elsevier Science, 71-80, 1995.

Sutton, M. A., Erisman, J. W., Dentener, F., and Moller, D.: Ammonia in the environment: From ancient times to the present, Environ. Poll., 156, 583-604, 2008.

Sutton, M. A., Nemitz, E., Erisman, J. W., Beier, C., Bahl, K. B., Cellier, P., de Vries, W., Cotrufo, F., Skiba, U., Di Marco, C., Jones, S., Laville, P., Soussana, J. F., Loubet, B., Twigg, M., Famulari, D., Whitehead, J., Gallagher, M. W., Neftel, A., Flechard, C. R., Herrmann, B., Calanca, P. L., Schjoerring, J. K., Daemmgen, U., Horvath, L., Tang, Y. S., Emmett, B. A., Tietema, A., Penuelas, J., Kesik, M., Brueggemann, N., Pilegaard, K., Vesala, T., Campbell, C. L., Olesen, J. E., Dragosits, U., Theobald, M. R., Levy, P., Mobbs, D. C., Milne, R., Viovy, N., Vuichard, N., Smith, J. U., Smith, P., Bergamaschi, P., Fowler, D., and Reis, S.: Challenges in quantifying biosphere-atmosphere exchange of nitrogen species, Environ. Poll., 150, 125-139, 2007.

Sutton, M. A., Nemitz, E., Milford, C., Campbell, C., Erisman, J. W., Hensen, A., Cellier, P., David, M., Loubet, B., Personne, E., Schjoerring, J. K., Mattsson, M., Dorsey, J. R., Gallagher, M. W., Horvath, L., Weidinger, T., Meszaros, R., Dämmgen, U., Neftel, A., Herrmann, B., Lehman, B. E., Flechard, C., and Burkhardt, J.: Dynamics of ammonia exchange with cut grassland: synthesis of results and conclusions of the GRAMINAE Integrated Experiment, Biogeosciences, 6, 2907-2934, doi:10.5194/bg-6-29072009, 2009.

Sutton, M. A., Nemitz, E., Theobald, M. R., Milford, C., Dorsey, J. R., Gallagher, M. W., Hensen, A., Jongejan, P. A. C., Erisman, J. W., Mattsson, M., Schjoerring, J. K., Cellier, P., Loubet, B., Roche, R., Neftel, A., Hermann, B., Jones, S. K., Lehman, B. E., Horvath, L., Weidinger, T., Rajkai, K., Burkhardt, J., Löpmeier, F. J., and Daemmgen, U.: Dynamics of ammonia exchange with cut grassland: strategy and implementation of the GRAMINAE Integrated Experiment, Biogeosciences, 6, 309331, doi:10.5194/bg-6-309-2009, 2009.

Sutton, M. A., Oenema, O., Erisman, J. W., Leip, A., van Grinsven, H., and Winiwarter, W.: Too much of a good thing, Nature, 472, 159-161, 2011.

Sutton, M. A., Pitcairn, C. E. R., and Fowler, D.: The exchange of ammonia between the atmosphere and plant communities, Adv. Ecol. Res., 24, 301-389, 1993.

Sutton, M. A., Tang, Y. S., Miners, B., and Fowler, D.: A new diffusion denuder system for long-term regional monitoring of atmospheric ammonia and ammonium, Water Air Soil Poll., 145-156, 2001. 
Tang, Y. S., Simmons, I., van Dijk, N., Di Marco, C., Nemitz, E., Dammgen, U., Gilke, K., Djuricic, V., Vidic, S., Gliha, Z., Borovecki, D., Mitosinkova, M., Hanssen, J. E., Uggerud, T. H., Sanz, M. J., Sanz, P., Chorda, J. V., Flechard, C. R., Fauvel, Y., Ferm, M., Perrino, C., and Sutton, M. A.: European scale application of atmospheric reactive nitrogen measurements in a low-cost approach to infer dry deposition fluxes, Agr. Ecosys. Environ., 133, 183-195, 2009.
Wichink Kruit, R. J. R., van Pul, W. A. J., Otjes, R. P., Hofschreuder, P., Jacobs, A. F. G., and Holtslag, A. A. M.: Ammonia fluxes and derived canopy compensation points over non-fertilized agricultural grassland in The Netherlands using the new gradient ammonia-high accuracy-monitor (GRAHAM), Atmos. Environ., 41, 1275-1287, 2007. 